\title{
Orman fonksiyonu mu ekosistem hizmeti mi?
}

\author{
Can Vatandașlara,* (i)
}

\begin{abstract}
Özet: Son dönemde ortaya çıkan ve dünyada giderek yaygınlaşan ekosistem hizmetleri (EH) yaklaşımı, Türkiye ormancılı̆̆ için oldukça yeni bir kavramdır. Ülkemizdeki orman EH ile ilgili az sayıdaki çalışma, son yıllarda yürütülmeye başlanmıştır. Söz konusu çalışmalarda, orman fonksiyonları (OF) ve EH kavramlarının sıklıkla birbirine karıştırıldıkları ya da eşanlamlıymış gibi kullanıldıkları görülmektedir. Bu durum, sınıflandırma, sayısallaştırma ve haritalama gibi bilimsel değerlendirmelerde yanıltıcı verilerin üretilmesine neden olmaktadır. Dolayısıyla, ileride politika yapıcı ve karar vericilere hatalı bilgilerin sunulma riski söz konusudur. Bu çalışmanın amacı; OF ve EH kavramları arasındaki ayrım çizgisinin netleştirilerek EH yaklaşımının ormancılık sektörümüze sunabileceği olanakların gösterilmesidir. Bu amaçla, OF ve EH kavramları birbirinden bağımsız şekilde ele alınarak tanıtılmış, her iki yaklaşımın ormancılıktaki uygulamaları analiz edilmiş ve birbirlerine karşı zayıflık ve üstünlükleri ortaya konmuştur. Bununla beraber, EH basamak modeli ilk kez orman ekosistemine uyarlanmış; böylelikle, OF ve EH arasındaki bağlantılar hem teorik hem de ormancılıktan somut örneklerle gösterilmiştir. Son olarak, Türkiye orman kaynaklarının EH, Uluslararası Ortak Sınıflandırma Sistemi (CICES) uyarınca hiyerarşik olarak listelenmiştir. Çalışmanın sonucunda; ormanlardan çok amaçlı faydalanma için EH yaklaşımının, OF yaklaşımına nazaran daha kullanışlı olduğu değerlendirilmiştir. Türkiye ormancılığında EH yaklaşımının benimsenmesi halinde, ekosistem tabanlı fonksiyonel (çok amaçlı) planlama (ETFOP\&ETÇAP) sisteminin bazı eksiklikleri de giderilmiş olacaktır. Diğer yandan, ülkemizde EH'ne ilişkin çalışma yürütecek araştırmacıların önünde oldukça uzun bir yol bulunmaktadır. Araştırmacılar, bugüne dek sayısallaştırılmamış olan birçok orman EH (termal konfor, karizmatik türler, kültürel miras vd.) için kantitatif göstergeler geliştirerek ve bunlara ekonomik değer takdir ederek işe koyulabilirler. Yolun sonunda, orman kaynaklarımızın doğal sermayeye olan katkısı belirlenmiş olacaktır.
\end{abstract}

Anahtar kelimeler: Orman fonksiyonları, Orman ekosistem hizmetleri, Üretim hizmetleri, Düzenleme ve koruma hizmetleri, Kültürel hizmetler

\section{Resolving the ambiguity: Forest function or ecosystem service?}

\begin{abstract}
Ecosystem services (ES) have become one of the most popular concepts in environmental research over the last decades. Nevertheless, the concept is quite new for the Turkish forestry sector. The number of national ES studies is very limited, and they have been conducted in recent years. Moreover, the term ES is often confused with forest functions (FF) in the literature. Such confusion may yield deceptive results stemming from inaccurate scientific assessments, including classification, digitizing, and mapping schemes. In this case, policy- and decision-makers will be misinformed in the future. This study aims to differentiate the ES and FF concepts explicitly and introduce the ES concept's opportunities to Turkish forestry. To this end, the ES and FF terms were separately identified, forestry applications using these concepts were thoroughly examined, and the two concepts were compared with each other from a forest management point of view. Furthermore, the ES cascade model was adapted to forest ecosystems, and thus, the cause-and-effect relationship between ES and FF was indicated with real-world examples from the sector. Finally, the ES of Turkey's forests were systematically documented based on the Common International Classification of Ecosystem Services (CICES) for the first time. The results showed that the ES concept was more useful than the FF for multipleuse forestry. Specifically, the ecosystem-based multifunctional forest management planning (ETFOP\&ETÇAP) system can greatly benefit from adopting the concept. However, the ES is a relatively novel research area in Turkey, and thus, researchers have a long way ahead. They may begin the work by developing ecological indicators for unquantified ES or monetarizing the intangible ES, such as thermal comfort, and cultural heritage. Thus, the contribution of Turkey's forests to the natural capital will be able to unveil in time.
\end{abstract}

Keywords: Forest functions, Forest ecosystem services, Provisioning ecosystem services, Regulating and maintenance ecosystem services, Cultural ecosystem services

\section{Giriş}

20. yüzyılın ikinci yarısında, uluslararası çevresel süreçlerin de teşvikiyle (UNCED, 1992; Resolution H1, 1993), ormanları "odun deposu" olarak gören ve buna göre planlayan işletmecilik anlayışı terk edilmiştir. Bunun yerini, orman ekosistemleri tarafindan sunulan karbon depolama, su rejimini düzenleme ve biyoçeşitlilik gibi birçok değeri bütünsel olarak ele alan ve bu değerlerden de sürdürülebilir şekilde faydalanmayı amaçlayan modern ormancılık yaklaşımları almıştır. Bu kapsamda, Türkiye'deki amenajman yönetmeliği 2008 y1lında yenilenmiştir (OGM, 2008). Halen yürürlükte olan yönetmeliğe göre, ülkemizdeki orman amenajman planları Sürdürülebilir Orman Yönetimi $\llbracket$ a Artvin Çoruh Üniversitesi, Orman Fakültesi, Orman Mühendisliği Bölümü, Artvin

@ * Corresponding author (İletişim yazarı): canvatandaslar@ artvin.edu.tr

$\checkmark \quad$ Received (Geliş tarihi): 08.03.2021, Accepted (Kabul tarihi): 28.05.2021
Citation (Atıf): Vatandaşlar, C., 2021. Orman fonksiyonu mu ekosistem hizmeti mi? Turkish Journal of Forestry, 22(2): 171-185. DOI: $\underline{10.18182 / \mathrm{tjf} .892837}$ 
(SOY) ilkeleri uyarınca 'Ekosistem Tabanl Fonksiyonel Planlama (ETFOP)' sistemiyle hazırlanmaktadır (Asan, 2017).

$\mathrm{Bu}$ süreçte orman fonksiyonları (OF) kavramı, sürdürülebilir ve fonksiyonel (çok amaçlı) ormancılı̆̆ın ayrılmaz bir parçası olmuştur. Ülkemizin de içinde bulunduğu Forest Europe (pan-Avrupa) sürecinde ve SOY tanımında kendine yer bulan OF kavramı tüm dünyada popülerleşmiştir (Resolution H1, 1993). Özellikle kıta Avrupası ve Türkiye gibi Orta Avrupa ormancılık ekolünden etkilenmiş ülkeler, bu kavramı kendi ormancılık uygulamalarında etkin bir şekilde kullanmaktadırlar (Kindler, 2016; OGM, 2017; Boncina vd., 2019). OF kavramı Asan (2017) tarafindan; orman ekosistemindeki ekolojik süreçler ve ekosistem bileşenleri arasındaki karşıllıklı ilişkiler sonucunda doğal olarak ortaya çıkan ürün ve hizmetler olarak tanımlanmaktadır. Bunlar; parasal değeri doğrudan hesaplanabilen somut çıktılara sahip fonksiyonlar olabileceği gibi (örn. odun üretimi), parasal değerinin dolaylı yöntemlerle hesaplanabildiği çıktılar sunan fonksiyonlar da olabilirler (örn. gen koruma). Hatta ormanların sanatçılara ilham kaynağı olması gibi, maddi karşılığını belirlemenin oldukça zor olduğu soyut fonksiyonlar da doğada kendiliğinden yer almaktadır (de Groot, 1992).

İster somut ister soyut olsun orman ekosisteminde kendiliğinden ortaya çıkan bir fonksiyona, toplum tarafından talep var ise; o fonksiyon ormanın işletme amacı ya da koruma hedefi olur (OGM, 2017). Bu amaç ve/veya hedefler, orman planlamacıları tarafından orman işletme şefliklerinin bütünü ya da belirli işletme sınıfları için katılımcı bir yaklaşımla belirlenir ve önceliklendirilir (ana amaç, yan amaç, bayrak tür gibi). Daha sonra ilgili işletme sınıfları, söz konusu amaç veya amaç kombinasyonlarını en üst düzeyde temin edecek şekilde planlanıp işletilirler (Başkent vd., 2008; Zengin vd., 2013; OGM, 2017). Böylelikle, hem toplumun orman ürün ve hizmetlerine olan ihtiyaçları karşılanmış hem de orman sahibine (ülkemizde OGM) maddi gelir sağlanmış olur. Bu yüzden OF yaklaşımı, 20. yüzyılın ikinci yarısından itibaren gerek bilimsel araştırmalarda (örn. fonksiyonların sınıflandırılması, sayısallaştırılması), gerekse ormancılık uygulamalarında (örn. fonksiyon haritaları, fonksiyonel eta) önemli bir yer tutmaktadır (Dieterich, 1953; Asan ve Şengönül, 1988; Eraslan ve Şad, 1993; Keleş vd., 2017; Şengönül ve Şahin, 2017; Boncina vd., 2019).

Küresel ölçekte yaşanan çevresel tahribatlarla birlikte 21 . yüzyıla giren insanoğlu, doğanın korunması ve ekonomik kalkınma kıskacında devamlı yeni arayışlar içerisinde olmuştur. $\mathrm{Bu}$ süreçte ekosistem hizmetleri (EH) kavramı ortaya çıkmış (Costanza vd., 1997; Daily, 1997) ve kavramsal çerçevesi çizilmiştir (MEA, 2005; de Groot vd., 2010; Potschin ve Haines-Young, 2011). Akabinde, EH yaklaşımı yaygınlaşmış ve kendine önemli uygulama alanları bulmuştur (MAES, 2011; TEEB, 2011; IPBES, 2018). Son y1llarda EH alanında yapılan çalışmaların ivmelenerek arttığı net bir şekilde görülmektedir (Boerema vd., 2017).

$\mathrm{EH}$ terimi kisaca; toplumların ekosistem fonksiyonlarından doğrudan veya dolaylı olarak sağladığı faydalar olarak tanımlanabilir (Burkhard vd., 2014). EH yaklaşımı (konsepti) ise; bu faydaların belirlenmesi, sayısallaştırılması, haritalanması ve parasal değer takdiri yoluyla ekosistemin yapısı, süreçleri, fonksiyonları ve toplumların refahı arasındaki ilişkileri değerlendiren geniş bir disiplin olarak karşımıza çıkar (Burkhard ve Maes, 2017). EH yaklaşımı, bütüncül ve problem odaklı bir yapıya sahiptir. Bu sayede çeşitli EH arasındaki sinerji (ahenk) ve çelişkilerin de değerlendirilmesinde kolaylık sağlanır. Örneklendirmek gerekirse; ormanın sağladığı üretim hizmetlerinden odun üretimini arttırmayı amaçlayan bir yönetim stratejisinin, ormandaki düzenleme ve koruma hizmetlerinden biyoçeşitlilik ya da su kalitesinin korunmasını olumsuz yönde etkileyeceği kuvvetle muhtemeldir. Dolayısıyla orman planlamacısı burada bir karar verme problemiyle karşı karşıya kalır: Ya odun üretimi miktarından ödün vererek -örneğin- ormandaki boz ayı popülasyonunu arzu edilen seviyede tutacaktır ya da odun üretimini maksimize edip yaban hayatından feragat edecektir. İşletme amacı uyarınca iki seçenekten biri seçilebileceği gibi, ormanın sunduğu her iki EH'nin aynı alan üzerinde eşzamanlı temini de mümkündür. Böyle bir tercih yapılması durumunda, çok amaçlı faydalanmanın optimize edilebilmesi için EH'nin sayısallaştırılmasına ve ödünleşim (trade-off) analizlerine ihtiyaç duyulur. $\mathrm{Bu}$ analizler, planlamacılara nicel bilgiler sunarak orman kaynakları hakkında daha doğru kararlar alınmasını sağlar (Başkent, 2018). Sonuç itibariyle, EH yaklaşımı çok amaçlı orman amenajmanında sıklıkla yararlanılan bir araca dönüşmüştür (Kindler, 2016; Hansen ve Malmaeus, 2016; Maes vd., 2018). Hatta İngiltere, kendi ormancılık sektöründe son 25 yıldır hakim olan SOY dönemini kapatarak onun yerine -daha kullanışlı olduğunu düşündükleri- EH yaklaşımını benimsemişlerdir (Quine vd., 2013; Sing vd., 2015).

Türkiye'de OF yaklaşımı ve OF'nın amenajman planlarına yansıtılmasıyla ilgili geçmişten beri birçok çalışma yapılmış olmasına rağmen (Asan, 1990; Yılmaz, 2004; Karahalil vd., 2009; Yüksel vd., 2013; Keleş vd., 2017; Şengönül ve Şahin, 2017; Mutlu ve Cengiz, 2017), orman EH ile ilgili çalışmalar oldukça azdır. Var olan sınırlı sayıdaki çalışma ise son yıllarda gerçekleştirilmiştir (Uygur Erdoğan, 2017; Eker, 2018; Vatandaşlar vd., 2020; Başkent, 2020; Özdemir vd., 2020). Ancak, söz konusu çalışmaların çoğunda OF ile orman EH'nin birbirine karıştırıldığı anlaşılmaktadır. Oysa ikisi arasında hem terminolojik hem de kavramsal anlamda önemli farklılıklar bulunmaktadır. Bu farklılıklar OF ve EH'nin konumsal ve zamansal olarak birbirinden ayrışmasına neden olmaktadır (Burkhard ve Maes, 2017). Bu ayrımın görmezden gelinmesi, başta ekonomik fonksiyonlar olmak üzere diğer birçok OF'na yanlış değer takdir edilmesine (biyofiziksel+parasal) yol açabilir. Böyle bir ortamda karar vericilere yanıltıcı bilgilerin sunulması kaçınılmazdır.

Bu çalışmanın amacı; OF ve EH kavramları arasındaki çizginin kalınlaştırılarak, her ikisi için yapılacak ekolojik değerlendirmelerin birbirinden ayrılmasını sağlamaktır. Bu amaçla, çalışmanın 2. bölümünde $\mathrm{OF}$ kavramı ve ormancılıktaki uygulamaları tarihsel olarak analiz edilmiştir. 3. bölümde, EH kavramı ormancılık bakış açısıyla derinlemesine incelenmiştir. 4. bölümde her iki yaklaşım arasındaki farklar ön plana çıkarılmış ve orman ekosisteminden somut örneklerle açıklanmıştır. Son bölümde ise 2,3 ve 4 . bölümlerde yapılan değerlendirme ve karşılaştırmalara dayanarak, EH yaklaşımının ormancılık sektörümüze sunduğu olanaklara yer verilmiş, geleceğe dönük bazı önerilerde bulunulmuştur. 


\section{Orman fonksiyonları}

\subsection{Tanım ve tarihçe}

Orman, yeryüzündeki onlarca farklı ekosistemden bir tanesidir. Bu yüzden OF'nı tanımlamadan önce ekosistem fonksiyonu üzerinde durmak gerekir. de Groot vd. (2002) ekosistem fonksiyonlarını "doğal süreç ve bileşenlerin insanoğlunun ihtiyaçlarını doğrudan veya dolaylı olarak karşılayan ürün ve hizmetleri sağlama kapasitesi" olarak tanımlamaktadırlar (s. 13). Bu bağlamda ekosistem fonksiyonu, ekolojik süreç ve ekosistem yapısının bir alt seti olarak anlaşılmalıdır. OF ise Asan (2013) tarafından; "orman ekosistemlerinin kendi doğal ortamlart içinde, bu ekosistemleri oluşturan canlı ve cansiz, mikro ve makro elemanlar arasındaki karşılıklı ilişki ve etkileşim süreci esnasında, zaman içinde ortaya çıkan ve bir bölümü toplum yararına kullanılan mal ve hizmetlerin tamamı" şeklinde tanımlanmaktadır (s. 37).

OF üzerine yapılan bilimsel çalışmalar, esasen çok eski tarihlere kadar uzanır. Ormanların odun üretimi haricinde kalan koruyucu fonksiyonları, 19. yüzyılın başlarında keşfedilmeye başlanmıştır (Zwerlein, 1806; Moreau de Jonnès, 1825). Ancak, teknik ormancılık anlamında OF'nın kavramsallaştırılması ilk kez 1953 yılında Dieterich (1953) tarafindan Almanya'da yapılmıştır (Alm: Waldfunktionenkonzept). Bu yaklaşımın temel amacı, farklı OF'nın uygun bir şekilde harmonize edilerek dengelenmesi ve böylelikle ormanlardan çok amaçlı faydalanmadır. Yaklaşım; OF'nın sınıflandırılması, sayısallaştııılması, haritalanması ve uygulamayı içermektedir.

\subsection{Orman fonksiyonlarının sinıflandırılması}

OF, yerli ve yabancı araştırmacılar tarafından çok farklı şekillerde sınıflandırılmıştır (Dieterich, 1953; Hasel, 1971; Henne, 1972; Kapucu, 2004; Asan, 2013). Bu kadar farklı sınıflandırmalar yapılmış olmasının nedenlerinden biri; toplumun ormandan beklentilerinin zamanla değişip çeşitlenmesidir. Bu dinamik süreç, geçmişte önemli görülen bazı OF'larının ikinci plana atılmasına ya da konjoktürel olarak yeni OF’nın keşfedilmesine neden olmuştur. Örneğin; sanayi devrimiyle başlayan endüstri çağında enerji kaynağ olarak kritik öneme sahip olan odun hammaddesi, günümüzde gelişmiş ülkeler tarafından ikincil fonksiyon olarak görülebilmektedir. Ya da son dönemlerde tüm dünyanın odağında olan küresel iklim değişimi, ormanların iklimi düzenleme fonksiyonunu ön plana çıkarmış ve yeni bir OF olarak karbon depolamayı gündeme getirmiştir.

Dünya genelinde geniş kabul gören sınıflandırma sistemi; çeşitli OF'larının ekonomik, ekolojik ve sosyokültürel gruplar altında toplanmasıdır (Resolution H1, 1993). Ekonomik fonksiyonlar; ormanların odun ve odun dış1 orman ürünleri (ODOÜ) üretim hizmetlerini kapsamaktadır. Bunlar fiziksel ve parasal olarak kolaylıkla kavranabilmekte ve genellikle belirli standartlara sokulabilmektedir. Ekolojik fonksiyonlar denildiğinde; ormanların doğal çevreye yaptıkları olumlu katkılar anlaşılır. Bu katkıların -genellikle- pazarı olmadığı için parasal anlamda kavranmaları güçtür (Kapucu, 2004). Sosyokültürel fonksiyonlar ise; ormanların toplum sağlığına, mutluluğuna, kültürüne ve gelişimine sağladığ 1 her türlü katkıdır. Bu katkıların sayısallaştırılması da tıpkı ekolojik fonksiyonlarınki gibi zordur. Uluslararası süreçlerden Forest Europe'da yer alan Türkiye'de de, OF bu şekilde sınıflandırılmaktadır. Ülkemizde üç ana fonksiyon grubu altında 10 genel OF belirlenmiştir (Eraslan ve Şad, 1993; Eraslan ve Eler, 2014; OGM, 2017). Genel OF altında da toplam 54 adet işletme amacı ve koruma hedefi bulunmaktadır (Ek Çizelge 1).

Türkiye orman varlığının alansal olarak \%42'si ekonomik, \%49'u ekolojik, \%9'u ise sosyokültürel fonksiyonlara ayrılmış durumdadır (OGM, 2020). Esasen, Orman Kanunu'nda devlet ormanları için vasıf ve karakter bakımından yapılan sınıflandırma da (istihsal ormanları, muhafaza ormanları, milli parklar), hemen hemen bu ana fonksiyonları karşılamaktadır (6831 sayılı O.K., 1956). Ek Çizelge 1'de sunulan sistematiğin hukuki açıdan ülke koşullarına uygun olduğu değerlendirilebilir. $\mathrm{Bu}$ uyum, özellikle Orman Kanunu'nun yürürlüğe girdiği yıl dikkate alındığında, Türkiye'deki ormancılık anlayışının -en azından teorik düzeyde- ne kadar ilerici olduğunu göstermesi bakımından anlamlıdır. Fakat geçmişte, sahada gerçekleştirilen bazı hatalı ormancılık faaliyetlerinin varlığı da bilinmektedir (Kose ve Baskent, 1997; Çolak vd., 2010; Zengin vd., 2013; Üzenge, 2013).

2.3. Orman fonksiyonlarının sayısallaştırılması ve haritalama

OF’nın doğru şekilde sayısallaştırılıp haritalanması oldukça önemlidir. Çünkü bu alanlar orman amenajman planlarında çeşitli ölçütlere göre ayrılarak bağımsız birer işletme sınıfi oluştururlar. Fonksiyonel alanların tahsisi aşamasında; (i) kanuni, teknik ve sosyokültürel ölçütler, (ii) katılımcı kuruluşların görüşleri, (iii) ormanın mevcut durumu ve fiili kullanımı dikkate alınır (OGM, 2017). Daha sonra orman işletme şefliklerinin OF haritası üretilir (Şekil 1). Orman amenajmanında OF haritaları belirleyicidir. Nitekim, farklı OF gören aynı meşcere tipleri için kararlaştırılan eta miktarları bile birbirinden farklı olabilmektedir. Buna fonksiyonel eta denir (Asan, 2017).

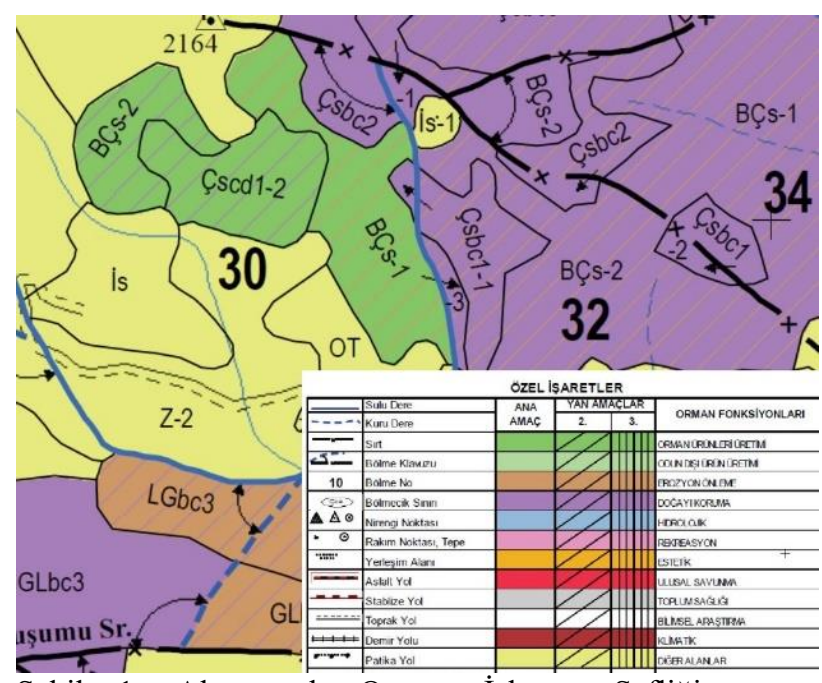

Şekil 1. Altıparmak Orman İşletme Şefliği orman fonksiyonları haritasından bir kesit (OGM, 2010) 
OF'nın haritalanmasıyla ilgili ilk talimatname, 1974'te Federal Almanya'da yayınlanmıştır (Henne, 1974). Talimatnamede, tüm OF'nın aynı anda aynı alandan sağlanması öngörülmektedir. Bu çerçevede, her orman işletmesinde tek bir silvikültürel rejim altında çoklu fonksiyonların sağlanması beklenmektedir. Ancak, ormancılık pratiği açısından bu çok zordur çünkü her meşcere tipinin silvikültürel reçetesi farklıdır. Ayrıca, belirli OF'nı en iyi biçimde yerine getiren orman formları da genellikle birbirinden ayrılmaktadır. Örneğin; yuvarlak odun üretimi açısından aynı yaşlı ve maktalı orman formu tercih edilirken, yüksek su kalitesi açısından değişik yaşlı ve düşey kapalı (seçme) ormanlar tercih edilmektedir (Asan, 2013). Dolayısıyla, uygulamada yaşanan başarısızlıklar söz konusu talimatnamenin revizyonunu gerektirmiştir. $\mathrm{Bu}$ vesileyle ormanın kullanım, koruyucu ve rekreasyon fonksiyonları eşit ağırlık kazanarak ilk kez 1983 yılında Federal Almanya'nın orman kanununa girmiştir (Bader ve Riegert, 2011).

Diğer ülkelerde farklı haritalama yöntemleri de söz konusudur. Örneğin Slovenya'da OF her alan için bağımsız olarak değerlendirilmekte ve fonksiyon haritaları üst üste çakıştırılarak çoklu fonksiyon gören ormanların nihai haritası üretilmektedir. Daha sonra fonksiyonların önem sırası belirlenerek önceliklendirme yapılmaktadır (Boncina vd., 2019). İsveç'te ise her alan ancak bir fonksiyona sahip olabilmektedir. Böylece çeşitli OF arasındaki potansiyel çelişkiler ortadan kaldırılmaktadır (Hanewinkel, 2011). Ülkemizdeki temel yaklaşım; ormanlardan çok amaçlı faydalanma şeklindedir. Diğer bir ifadeyle; belirli bir orman alanı aynı anda birden çok fonksiyon görecek şekilde planlanmaktadır (OGM, 2017). Bu amaçla; fonksiyonlardan biri ana amaç, diğer(ler)i yan amaç olmaktadır (Şekil 1). Buradaki kritik nokta; tüm ana ve yan amaçların birbirleriyle uyum içerisinde olmasıdır. Endüstriyel ağaçlandırma ve estetik görünüm gibi birbiriyle çelişen amaçlar, her iki amacın da optimal düzeyde gerçekleştirilememesine neden olacaktır.

Türkiye'de OF terimi orman kanununda yer almasa da, çeşitli yönetmelik, tebliğ ve emirlerde geçmektedir (OGM, 2008; 2012; 2015; 2017). Bu mevzuatta fonksiyonel orman alanlarının ayrılmasıyla ilgili ayrıntılı ölçüt ve göstergeler bulunmaktadır. Örneğin; doğayı koruma fonksiyonu görecek ormanların ayrılma ölçütlerinden biri eğim, bu ölçütün nicel göstergesi ise \%80'dir (OGM, 2017). Diğer bir ifadeyle; yamaç eğimi \%80'nin üzerinde olan ormanlık alanlar, amenajman planlarında doğayı koruma fonksiyonuna ayrılmaktadır. $\mathrm{Bu}$ ormanlar $\mathrm{OF}$ haritalarında mor renkle temsil edilirler (Şekil 1). Doğayı koruma fonksiyonu gören ormanlardaki genel uygulama, planlı odun üretimi faaliyetlerinin yapılmaması yönündedir.

İlgili mevzuatta katılımcı yaklaşıma da yer verilmiştir. Bu bağlamda, toplumun orman ürün ve hizmetlerine duyduğu ihtiyacın daha iyi belirlenebilmesi için nihai OF haritası yapılmadan önce Orman Bölge Müdürlükleri tarafından muhtarlıklara, sivil toplum kuruluşlarına ve ilgili diğer örgütlere yazı gönderilir. Resmi yazıda, yapılacak çalışmalar hakkında genel bilgiler yer almaktadır (OGM, 2017). Gerekli görüldüğü takdirde yerel halkla bir araya gelinerek, taslak fonksiyon haritaları üzerinde tartışmaların yapıldığ toplantılar da düzenlenebilmektedir. Dolayısıyla, OF haritasının orman teşkilatı ve yerel halk arasında iletişim kurulması anlamında da önemli bir rol üstlendiğini söylemek yanlış olmaz.

\subsection{Uygulama}

Türkiye'de OF yaklaşımının uygulamaya aktarılması ETFOP ile sağlanmaktadır. Asan (2017) ETFOP'y1; “orman ekosistemlerinde kendiliğinden oluşan ürün ve hizmetleri, bu sistemleri oluşturan canlı ve cansız elemanların varlığını yok etmeden ve aralarındaki doğal süreçleri zedelemeden, Orman Amenajman disiplininin temel ilkelerini ve plan ünitelerinde öne çıkan konumsal fonksiyonları gözeterek sürekli ve kesintisiz biçimde alabilmek için, plan ünitelerinde öngörülen teknik, biyolojik, sosyal ve ekonomik etkinlikleri uzun ve orta vadeli stratejik öngörüler çerçevesinde yer ve zamana bağll olarak düzenleyen bir planlama sistemi" şeklinde tanımlamaktadır (s. 36). Sistemin özü; orman ekosisteminin uzun vadede sürdürülebilirliğini riske atmadan ekonomik, ekolojik ve sosyokültürel fonksiyonların katılımcı bir yaklaşımla dengelenmesine dayanmaktadır. Bu amaçla, Coğrafi Bilgi Sistemleri (CBS), uzaktan algılama (UA), küresel konum belirleme sistemleri (GPS), sayısal veri tabanları (ACCESS) ve amenajman plan programı (APP) gibi bilişim teknolojilerinden azami ölçüde yararlanılır.

Türkiye'de orman amenajman planları 2008 y1lından itibaren ETFOP sistemiyle yenilenmektedir (OGM, 2008). Gerek Orman İdaresi ve Planlama Daire Başkanlığı'nda gerekse özel ormancılık bürolarında görev yapan amenajman heyetleri ve deneticiler, ETFOP'ya kısa sürede uyum sağlayarak ciddi bilgi ve birikim sahibi olmuşlardır. Teknolojik cihaz ve yazılımların heyetler tarafından aktif kullanımı, planlama işinin geçmişe nazaran daha hızlı yapılabilmesine olanak sağlamaktadır. $\mathrm{Bu}$ anlamda, ekosistem tabanlı fonksiyonel orman amenajman planlarının hazırlanması günümüzde etkin bir şekilde gerçekleştirilmektedir. Ayrıca, OGM (2017) uyarınca hazırlanan planlar OGM (2015) uyarınca denetlenmektedir.

Türkiye'de uygulanan OF yaklaşımına ve ETFOP'ya dair bir takım eleştiriler de getirilmiştir. Bunlar aşağıdaki şekilde gruplandirılabilir;

- Ekolojik ve sosyokültürel fonksiyonlar ile meşcere yapısı arasındaki sayısal ilişkilerin kurulmamış olması (Başkent, 2018). Dolayısıyla birçok OF için optimal (hedef) meşcere kuruluşlarının belirsizliği,

- Bazı OF’nın ayrılmasında kullanılan ölçüt ve göstergelerin yetersizliği (Saraçoğlu, 2010; Şengönül ve Şahin, 2017; Vatandaşlar vd., 2020),

- Orman ürünleri (odun hammaddesi) üretimi fonksiyonuna, diğer OF'na nazaran daha fazla ağırlık verilmesi (Özdemir vd., 2020),

- Ormanlık alanların fonksiyonel tahsisinde ve işletme amaçlarının eniyilenmesinde, bilimsel karar verme tekniklerinden yararlanılmaması (Güngör, 2010; Başkent vd., 2013),

- Planlama sürecinde katılımcı yaklaşıma yeterince önem verilmemesi (Durkaya vd., 2013; Y1lmaz, 2013),

- Toplumun orman ürün ve hizmetlerine olan talebinin (işletme amaçları) nitelik ve nicelik olarak bilinmemesi, gelecekte değişebilecek ihtiyaçların bugünden kestirilmemesi (Çağlar, 2011; Sağkaya, 2020). 


\section{Ekosistem hizmetleri}

\subsection{Tanım ve tarihçe}

EH teriminin ilk kullanımı 1970'li yıllara kadar uzansa da, bugünkü anlamıyla bilimsel literatüre girmesi 1997 yılında olmuştur (Costanza vd., 1997; Daily, 1997). Costanza vd. (1997)'nin makalesinde yapılan tanımlamaya göre EH; "toplumlarm ekosistem fonksiyonlarından doğrudan veya dolaylı olarak sağladiğ l faydalar"dır (s. 253). Araştırmacılar bu makalede yeryüzündeki tüm ekosistemler tarafından sunulan EH'nin toplam ekonomik değerini yıllık 33 trilyon \$ olarak hesaplamışlardır. Bu değere doğal sermaye de (natural capital) denmektedir. Bu gelişmeler üzerine, 21. yüzyılın başında Milenyum Ekosistem Değerlendirmesi (MED) yapılmış ve burada EH kavramsallaştırılmıştır (MEA, 2005). MED'den sonra EH kavramı bilim dünyasının dışına taşmış; çevre politikacıları, ekonomistler ve doğa korumacılar arasında da yaygınlaştırmıştır (Pistorius vd., 2012). $\mathrm{Bu}$ bağlamda $\mathrm{EH}$ yaklaşımı; insanoğlunun ekosistemlerden sağladığı faydaların konumsal olarak belirlenmesi ve bunlara ekonomik değer takdir edilmesi yoluyla ekosistemlerin yapısı, süreçleri, fonksiyonları ve toplumların refahı arasındaki ilişkileri değerlendiren bilimsel bir araştırma alanı olarak tanımlanabilir (Burkhard ve Maes, 2017).

EH yaklaşımının daha iyi anlaşılabilmesi ve uygulamada birlik sağlanması açısından bazı teorik modeller geliştirilmiştir (örn. cascade model, tiered approach, ES bundles, blueprint vd.). Bunlardan belki de en önemlisi; de Groot vd. (2010) ve Potschin ve Haines-Young (2011)'in geliştirdiği basamaklı (cascade) modeldir. Basamaklı modelin, orman ekosistemlerine uyarlanmış hali Şekil 2'de görülebilir. Şekilde ormanın biyofiziksel yapısı; orta boy, yaş sınıfı, tepe tacı kapalılığı gibi meşcere parametreleriyle karakterize edilmektedir. Bunların birbirleriyle ve diğer ekosistem elemanlarıla etkileşimi sonucunda ekolojik süreçler meydana gelir ve böylece orman fonksiyonunun (OF) oluşmasına zemin hazırlanır. Orman EH esasen OF'ndan türetilirler ve günlük hayatta insanoğluna aktüel bir hizmet akışı sunarlar. İnsanlar bu EH akışından farkında olarak ya da olmadan fayda sağlarlar. Söz konusu fayda(lar) ekonomik değere dönüşebileceği gibi (dikili satış), parasal olarak değerlendirilmeyebilir de (oksijen üretimi). Sonuç itibariyle, orman eko-sistemi, sosyo-ekonomik sistem (pazar vb.) ve toplum refahına katkı sağlamış olur.

Son yüzyıllarda yaşanan hızlı sanayileşme ve nüfus artışı, toplumları ormanlardan daha fazla faydalanmak zorunda bırakmıştır. Şekil 2'de antropojenik etki olarak gösterilen baskı unsurları (aşırı kesim, açmacılık, hayvan otlatma vd.) orman eko-sistemine zarar verebilmektedir. $\mathrm{Bu}$ anlamda Orman Amenajmanı bir taraftan sosyal baskıyı kontrol etmeye çalışırken (orman koruma, endüstriyel plantasyonlar $\mathrm{vd}$.), diğer taraftan ormancılık faaliyetleri ile birçok $\mathrm{EH}$ akışının sürdürülebilirliğini sağlamak zorundadır (ara hasılat, rekreasyon vd.). Bu sayede Şekil 2'deki döngü sağlıklı bir şekilde sürüp gider. Hatalı orman amenajmanı uygulamaları, aşırı sosyal baskı gibi nedenlerle zincirin halkalarından biri ya da birkaçı kopar(1lır)sa, gelecek nesiller kritik EH'nden faydalanamayacaktır. Böyle bir durumda, yeryüzündeki insan yaşamının sürdürülebilirliği tehlikeye girer.

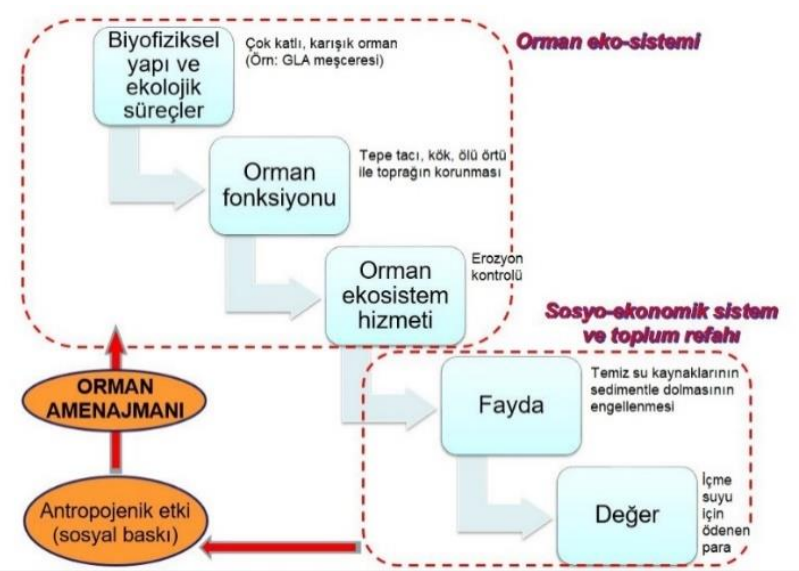

Şekil 2. EH yaklaşımına ilişkin basamak modeli (de Groot vd., 2010 ve Potschin ve Haines-Young 2011'den orman EH'ne uyarlanmıştır)

\subsection{Ekosistem hizmetlerinin sinıflandırılması}

EH çeşitli kesimlerce farklı şekillerde sınıflandırılmış olmasına rağmen ( $M E A, T E E B, I P B E S)$, günümüzde en sı k kullanılan sinıflandırma; Ekosistem Hizmetlerinin Uluslararas1 Ortak Siniflandirma Sistemi (EHUOS-CICES)' dir (Haines-Young ve Potschin, 2018; Tiemann ve Ring, 2018). EHUOS versiyon 5.1'e göre EH; (i) üretim, (ii) düzenleme ve koruma, (iii) kültürel hizmetler olarak üç ana gruba ayrılmaktadır (Haines-Young ve Potschin, 2018). Burada ekosistemlerden sağlanan somut (odun hammaddesi) ve soyut (jeotermal enerji) çıktılar, tek bir sınıf olarak üretim hizmetleri altında değerlendirilmiştir. Yine diğer sınıflandırmalardan farklı olarak EHUOS'ta destek hizmetleri de (örn. besin döngüsü), düzenleme ve koruma hizmetleri altında değerlendirilmektedir.

Üretim hizmetleri; canlı sistemlerden temin edilen gida, hammadde ve enerji kaynakları olarak tanımlanabilir (örn. tomruk [biyotik], içme suyu [abiyotik]). Düzenleme ve koruma hizmetleri; canlı organizmaların diş çevreyle etkileşime girerek insanların yaşamını güvence altına aldığ 1 tüm hizmetlerdir (Haines-Young ve Potschin, 2018). Ayrıca katı, sıvı ve gaz akışlarına elverişli ortamın temin edilmesi de bu sınıfa girmektedir (örn. vejetasyonun toprağı koruması [biyotik], devrik ağaçların fiziki engel oluşturarak taş yuvarlanmalarını önlemesi [abiyotik]). Kültürel hizmetler ise; ekosistemlerin insanların fiziki ve ruhsal sağlı̆ııı etkileyen tüm soyut ve tüketilemeyen çıktılarıdır (örn. doğa yürüyüşü için elverişli ortam oluşturma [biyotik], orman içinde gizli kalmış mağaralar [abiyotik]).

EH yaklaşımı yeryüzündeki tüm ekosistemleri kapsamaktadır. Bu çalışmanın kapsamı yalnızca ormanlarla sınırlı olduğu için EHUOS, orman ekosistemi özelinde sadeleştirilerek Ek Çizelge 2'de sunulmuştur. Ek Çizelge 2, yukarıdan aşağıya uzanan hiyerarşik bir sınıflandırma sistemine sahiptir (Haines-Young ve Potschin, 2018). Bu sisteme göre odun hammaddesi $\mathrm{EH}$; üretim hizmetleri ana grubunun altında, biyokütle bölümündeki ilgili alt sınıflarda yer alırken, orman içi su bentleri; yine üretim hizmetleri ana grubu altında, su kaynakları bölümündeki alt sınıfta yer almaktadır (Ek Çizelge 2). EHUOS'un bu hiyerarşik yapısı sayesinde, ormanlardaki karmaşık ekolojik süreç, döngü ve 
etkileşimler sonucunda ortaya çıkan tekil EH'nin ayrıntılı dökümü yapılabilmektedir.

\subsection{Ekosistem hizmetlerinin sayısallaștırılması ve haritalama}

EH'nin doğru şekilde sayısallaştırılabilmesi için amaca uygun göstergeler (indikatör) gereklidir. Bu göstergeler sayesinde ilgili EH, biyofiziksel birimlerle sayısal olarak ifade edilebilir. Örneğin; odun üretimi EH'nin göstergelerinden biri; yıllık eta miktarı, bunun biyofiziksel birimi ise $\mathrm{m}^{3} / \mathrm{ha} / \mathrm{y}$ l'dır. Diğer önemli EH'ne ait bazı göstergeler Çizelge 1'de toplu olarak sunulmuştur. EH göstergelerinin bir başka görevi de; ilgili EH'lerin arzında zaman içinde meydana gelen değişimleri ölçmektir. Böylelikle, herhangi bir orman işletmesinin sunduğu -örneğin- biyoçeşitlilik EH düzeyinin geçmişten günümüze seyri takip edilebilir (Burkhard ve Maes, 2017).

Sayısallaştırma için uygun göstergeler seçildikten sonra sıra, bu göstergelerin nasıl ölçüleceğine gelir. Burada üç farklı yaklaşım söz konusudur: (i) doğrudan ölçüm, (ii) dolaylı ölçüm, (iii) modelleme. Doğrudan ölçümler; söz konusu EH'nin durumunu envanter, gözlem, anket ve izleme gibi yöntemlerle tespitine dayanır (Vihervaara vd., 2017). Orman envanteri sirasında hesaplanan meşcere parametrelerinden y1llık hacim $\operatorname{artımı~}\left(\mathrm{m}^{3} / \mathrm{ha}\right)$, odun üretimi EH potansiyelinin doğrudan ölçülmesine güzel bir örnektir. Doğrudan ölçümlerle elde edilen bilgilere birincil veri denir (Egoh vd., 2012). Bunlar ilgili EH'nin sayısallaştırılması için kullanılabilecek en doğru veri kaynaklarındandır. Ancak doğrudan ölçümün geniş orman alanlarında gerçekleştirilmesi oldukça masraflı, zahmetli ve zaman alıcı olabilmektedir.

Dolaylı ölçümler de tıpkı doğrudan ölçümler gibi somut biyofiziksel veriler sağlar. Fakat bu veriler ilgili EH'ni direkt olarak ölçmeye izin vermez. Bu yüzden dolaylı ölçümle elde edilen veriler önce yorumlanır, işlenir ya da diğer verilerle harmanlanır (Vihervaara vd., 2017). Örneğin; kent ormanlarının havayı filtre etme EH, ağaçların yaprak alan indeksi (YAİ) yardımıyla ölçülebilmektedir. YAİ esasen havadaki tozları bizatihi tutmamaktadır. Ancak, ağaçların tepe ve dallarındaki ibre ve yaprak miktarı arttıkça, havadaki toz partiküllerinin bu engellere daha fazla takılarak havadan süzüleceği açıktır. Dolayısıyla, YAİ gibi indislere yardımcı (proxy) ya da ikincil göstergeler denmektedir (Egoh vd.,
2012). Dolaylı ölçümler genellikle uzaktan algılama yöntemleriyle gerçekleştirilirler. Bu yüzden daha kolay, hızlı ve ucuz yolla temin edilmeleri mümkündür. Fakat doğrulukları doğrudan ölçümlere nazaran daha düşüktür.

Modelleme; doğrudan ve dolaylı ölçümlerin mümkün olmadığı durumlarda ya da bazı düzenleme ve koruma $\mathrm{EH}$ için tercih edilmesi gereken bir yöntemdir. Modelleme ile karmaşık süreçler içeren EH'nin durumu, ekolojik ve sosyokültürel verilere dayalı olarak sayısallaştırılabilmektedir (Vihervaara vd., 2017). Örneğin; ormanların sıvı akışları düzenlemeyle ilgili EH'nin sayısallaştırılmasında kullanılan Soil and Water Assessment Tool (SWAT), modellemeye örnek teşkil edebilir. Fakat SWAT modelinin biyofiziksel çıktıları (örn. sediment miktarı) bu amaçla direkt olarak kullanılamaz. Söz konusu çıktıların başka bir model yardımıyla ilgili EH'ne (örn. sedimentasyonun su kalitesine etkisi) dönüştürülmesi gerekir (Dunford vd., 2017). Yine sıvı akışlarla ilgili diğer bir örnekte; Uygur (2016), ormanlık havzalarda hidrolojik döngünün düzenlenmesi ve sel/taşkından koruma EH'ni sayısallaştırmıştır. Bunun için Mike 11 hidrolojik yazılımının NAM yağış-akış modülünü kullanan araştırmacı, daha sonra model çıktılarını arazi kullanımları ile ilişkilendirmiştir. Böylelikle alt havzalardaki tüm arazi kullanım tipleri için yüzeysel akış katsayıları hesaplanabilmektedir. Çalışmanın sonunda orman, mera, tarım ve yerleşim arazi kullanımları için hesaplanan akış katsayıları sırasıyla; 0.32, 0.55, 0.61 ve 0.98 'dir. Diğer bir ifadeyle, ormana düşen toplam yağış miktarının yaklaşık 1/3'ü yüzeysel akışa geçerek yamaçlardan derelere ve mansaba ulaşırken, aynı yağışın geçirimsiz tabakaya sahip yerleşim yerlerine düşmesi halinde neredeyse tamamı yüzeysel akışa geçerek sel/taşkın gibi felaketlere yol açabilmektedir.

$\mathrm{EH}$, yukarıda açıklanan yöntemlerden uygun olan seçilerek sayısallaştırıldıktan sonra haritalanmalıdır. Çünkü özellikle ormanlarda neredeyse tüm EH'nin temin düzeyi, onların coğrafi konumlarıyla yakından ilişkilidir. Örneğin; dere kenarında yer alan (riperyan) meşcerelerin, drenaj ağına uzak bir başka meşcereye göre çok daha yüksek düzeylerde sediment önleme EH sunması beklenir. Ya da içinden araç yolu geçen meşcerelerde yaban hayatı $\mathrm{EH}$ düzeyinin düşeceği açıktır. EH haritalarının bir diğer faydası ise; planlamacı ve karar vericilere neredeki EH'nin güçlendirilmesi ve koruma faaliyetlerine nerelerden başlanması gerektiğiyle ilgili bilgiler sunmasıdır (Syrbe vd., 2017).

Çizelge 1. Bazı orman EH'ne ilişkin sayısal göstergeler

\begin{tabular}{|c|c|c|}
\hline Ekosistem hizmeti & Örnek göstergeler & Birimi \\
\hline Odun hammaddesi & Eta, gerçekleşen odun üretimi miktarı & $\mathrm{m}^{3} / \mathrm{ha} / \mathrm{y} 1 \mathrm{l}, \mathrm{m}^{3}$ \\
\hline Odun dişı orman ürünü & Ormandan toplanan mantar miktarı & ton/ha/yil \\
\hline Su üretimi & $\begin{array}{l}\text { Bentlerden şehir şebekesine aktarılan su miktarı, hidrolojik fonksiyon gören ormanın tüm alana } \\
\text { oranı }\end{array}$ & $\mathrm{m}^{3} / \mathrm{y} 11, \%$ \\
\hline Sel ve taşkın kontrolü & Sel sayıs1, selden etkilenMEyen alanlar & \#/yıl, ha \\
\hline Tozlaşma & Polen taşıyıcı böcek türlerinin bolluğu, orman kenar oranı & Tür sayıs1 $/ \mathrm{m}^{2}, \%$ \\
\hline Erozyon kontrolü & Önlenen toprak kaybı miktarı & ton/ha/y1l \\
\hline İklim düzenleme & Toprak/toprakaltı/toprak üstü bileşenlerdeki karbon stoğu, net $\mathrm{CO}_{2}$ bağlama miktarı & ton/ha, ton/y1l \\
\hline Ayrışma ve bağlama süreçleri & Nitrojen bağlayıcı türlerin yayılış alanı & ha \\
\hline Rekreasyon & Milli park ziyaretçi istatistikleri & Ziyaretçi sayısı/yıl \\
\hline
\end{tabular}


Arazi kullanımı/arazi örtüsü (AKAÖ) haritaları, EH haritalarına altlık oluşturabilir (Burkhard vd., 2009). Orman ekosistemi özelinde düşünürsek, meşcere haritasındaki her bir meşcere tipinden temin edilebilecek $\mathrm{EH}$ düzeyleri farklıdır. Örneğin; 15 yaşındaki gevşek kapalı Meşe baltalığ (MBt1/15) tarafından sunulan su üretim $\mathrm{EH}$ düzeyinin, Göknarın yaşlı seçme kuruluşundan (GA) fazla olması beklenir. Çünkü MBt1/15 kışın yapraklarını dökerek toprağı tüm yıl boyunca tam olarak örtemediği gibi, kısa idare süreleriyle tıraşlama kesildiği için bazı yıllarda toprağı tamamen çıplak bırakmaktadır. Böyle bir arazide yağmur sularının yüzeysel akışa geçme oranı ve dolayısıyla suyun havza su rezervuarlarında birikimi fazla olacaktır. GA kuruluşu ise hem yatay hem de dikey yönden tam kapalı olduğu için yağmur sularının önemli bir kısmı toprağa hiç ulaşamadan sik ibrelerden atmosfere geri buharlaşacaktır (intersepsiyon). Ayrıca üzerinde yüksek miktarda ağaç serveti bulunduran GA, terleme (transpirasyon) yoluyla topraktan ekstra su kaybına da neden olabilir. Dahası, seçme ormanlarda idare süresi ve makta kavramları olmadığı için gençleştirmeler tek ağaç düzeyinde yapılmakta; dolayısıyla, orman örtüsü toprağı sürekli olarak kapatmaktadır (bkz. devamlı orman-continuous cover forestry) (Gadow vd., 2002). Aynı meşcere tipleri, örneğin erozyonu önleme ya da biyoçeşitlilik EH açısından karşılaştırıldığında, tam aksi sonuçlarla karşılaşılması kuvvetle muhtemeldir. İşte bu yüzden tüm EH ayrı ayrı değerlendirilmeli ve haritalandırılmalıdır.

EH haritalanmasında farklı yöntemler söz konusudur. Bunlar; (i) kılavuz tablo (matris), (ii) uzman görüşü, (iii) fonksiyonel ilişki, (iv) yersel ölçme ve (v) konumsal modelleme olarak sinıflandırılabilir. Haritacının hangi yöntemi tercih edeceği, çalışmanın amacına ve veri teminine bağlıdır. Karar verme noktasında aşamalı yaklaşımın (tiered approach) kullanılması yardımcı olabilir (Gret-Regamey vd., 2015). Bu yaklaşıma göre; yeterli miktarda ve kalitede altlık veri sağlanamıyorsa genellikle i. ya da ii. yöntem kullanılmak zorundadır. Bu yöntemler ile söz konusu EH'nin yalnızca alansal dağılımı hakkında kaba bilgiye sahip olunabilir. Ĕger sistemin genel davranışı kavranmak isteniyorsa, iii. veya iv. yöntemler kullanılmalıdır. v. yöntem ise; sistemdeki süreçlerin arkaplanında yatan sebep-sonuç ilişkilerini (etkitepki vs.) açığa çıkartır. Tahmin edilebileceği gibi, i.'den v. yönteme doğru gidildikçe, hem veri ihtiyacı hem de harita doğruluğu tedricen artmaktadır. (Burkhard ve Maes, 2017).

\subsection{Uygulama}

EH yaklaşımı, bütüncül ve problem odaklı yapısı sayesinde günümüzde doğa koruma, doğal kaynak planlaması ve çevre yönetimi alanlarında sıklıkla tercih edilen bir uygulama aracına dönüşmüştür (Hauck vd., 2013; Tezer vd., 2018). Örneğin; Türkiye'nin de imza koyduğu Biyoçeşitlilik Sözleşmesi kapsamında taraf ülkelerce benimsenen Stratejik Plan'da Aichi Biyoçeşitlilik Hedefleri belirlenmiştir (European Commission, 2011). Buradaki Hedef 11 ve Hedef 14, direkt olarak EH ile alakalıdır. Avrupa Birliği ülkeleri söz konusu hedefleri yerine getirebilmek için kendi biyoçeşitlilik stratejilerini güncellemişlerdir. $\mathrm{Bu}$ bağlamda, 2020 yılına kadar kendi sınırlarındaki EH'nin durumunu haritalayıp değerlendirmek ve bozuk ekosistemlerin en az \%15'inde koruma ve restorasyon yapmak gibi somut hedefler koymuşlardır. Aynı süre zarfında ormancılık sektörünün biyoçeşitliliğin sürdürülmesine olan katkısının da arttırılması beklenmektedir (European Commission, 2011; IPBES, 2018). Bu yüzden aşağıda sıralanan çalışma grupları ve uluslararası girişimler, EH yaklaşımını fonksiyonel bir uygulama aracı olarak kullanmış ya da kullanmaktadırlar:

- Milliennium Ecosystem Assessment (MEA, 2005),

- The Economics of Ecosystems and Biodiversity (TEEB, 2011),

- Mapping and Assessment of Ecosystems and their Services (MAES, 2011),

- Intergovernmental Platform on Biodiversity and Ecosystem (IPBES, 2018).

EH yaklaşımının uygulamaya aktarılabilmesi için geliştirilmiş bir takım model yazılımlar da mevcuttur. $\mathrm{Bu}$ yazılımlar sayesinde birçok $\mathrm{EH}$ sayısallaştırılıp haritalanabildiği gibi, ekosistemlerin farklı bileşenleri arasındaki etkileşimler, alternatif senaryolar aracılığıyla geleceğe dönük olarak analiz edilebilmektedir. InVEST, ESTIMAP, ARIES, GISCAME ve MIMES, dünyada yaygin olarak kullanılan EH yazılımlarından bazılarıdır. Bunlardan GISCAME'i kullanan araştırmacılardan Frank vd. (2014), erozyon kontrolü EH'ni güçlendirmek için yapılacak amenajman uygulamalarının diğer EH'lerini nasıl etkileyeceğini araştırmıştır. Senaryo analizlerine dayalı model çıktıları; dere kenarlarının bitkilendirilmesi sonucunda toprak kaybında \%2-7, yamaçlara canlı/cansız çit yapımına ilaveten işlemeli tarımın terk edilmesi halinde \%33-89 ve üç faaliyetin birden yapılması durumunda toprak kaybında \%92'lik düşüş öngörmüştür. Ayrıca söz konusu faaliyetler ile alandaki ekolojik bütünsellik arasında da sinerji olduğu, fakat bunun odun üretimini olumsuz etkileyeceği sonucuna varılmıştır. Başkent (2018) ve Tiemann ve Ring (2018), bu tür ödünleşim (trade-off) analizlerini içeren model yazılımlarının çok amaçlı ormancılık açısından önemine vurgu yapmaktadırlar. Nitekim, farklı yönetim stratejilerinin gelecekteki EH temini üzerine etkilerini bilmek, bugünkü planlama kararlarının daha isabetli verilmesine yardımcı olacaktır.

$\mathrm{Bu}$ anlayışla ülkemizdeki bazı EH'ni orman amenajman planlarına yansıtan çalışmalar da mevcuttur. Örneğin; Vatandaşlar (2020) ormanların erozyon kontrolü EH'ni ETFOP'a entegre etmeye çalışmıştır. Bu amaçla, iki orman işletme şefliğinin potansiyel toprak kayıpları ve yerinde tutulan toprak miktarları (azaltılan erozyon) tahmin edilmiş, toprak korumaya ayrılması gereken meşcereler belirlenmiş ve toprak koruma işletme sınıflarında erozyonu minimize edecek optimal orman kuruluşları ortaya konmuştur. Sonuç olarak; normal (>\%10) kapalılıktaki meşcerelerin sahadaki erozyonu çıplak saha koşullarına göre \%95 oranında azaltabildikleri; seçme kuruluş ve tam kapalı ibreli meşcerelerde neredeyse hiç erozyon meydana gelmediği; sarıçamın toprak koruma işletme sınıflarında erozyon kontrolü EH'ni maksimize etmek için amaç meşcere kuruluşlarının $55 \mathrm{~m}^{2} /$ ha göğüs yüzeyine sahip olması gerektiği ve bu işletme sınıfi için gerekli olan optimal idare süresinin 100-120 yıl olduğu ortaya konmuştur. Ayrıca, böyle bir entegrasyon stratejisinin benimsenmesi halinde plan süresince alınacak periyodik eta miktarlarında herhangi bir azalma olmayacağı da gösterilmiştir. Çünkü bu yaklaşım ile erozyon açısından riskli görülmeyen meşcereler sırf eğimli 
arazi üzerinde bulundukları için toprak korumaya ayrılmak zorunda kalmamaktadır. Nitekim, arazi eğiminin haricinde erozyon riskini belirleyen bir çok faktör bulunmaktadır (örn: bitki örtüsü, iklim, toprak yapısı vd.). Bir başka araştırmada, Özdemir vd. (2020) su verimi, su kalitesi, akış değişkenliği ve ekstrem akışlara odaklanarak ormanların su üretimi EH'ni Marmara Bölgesi ölçeğinde çalışmışlardır. Çalışma sonucunda planlamacı ve uygulamacılara bir takım öneriler getirilmiştir. Bunlardan bazıları; su verimini arttırmak için şiddetli aralamalara başvurulmaması, ormancılık faaliyetleri esnasında ölü örtüye zarar verilmemesi, baraj havzalarında geniş yapraklı ağaç türlerinin tercih edilmesi ve su kaynaklarını korumaya yönelik "İyi Uygulama Rehberleri”nin hazırlanması şeklindedir.

EH kavramı ülkemizde nispeten yeni olduğu için, ulusal literatürde EH yaklaşımına karşı getirilen eleştirilere henüz rastlanmamaktadır. Ancak, uluslararası arenada ender de olsa eleştirilere rastlamak mümkündür. Bunlar genellikle $\mathrm{EH}$ için ücret ödeme mekanizmaları (payment for ecosystem services-PES, willingness to pay-WTP) konusunda yoğunlaşmaktadır. Bazı araştırmacılar PES mekanizmasının fazla piyasa güdümlü olduğunu öne sürmektedir. $\mathrm{Bu}$ durumun, doğaya "faydacı" bir gözle bakılarak, onun para karşılı̆̆1 sömürülmesine hizmet edebileceği noktasında uyarılar yapılmaktadır (Pistorius vd., 2012; GómezBaggethun vd., 2010; Quine vd., 2013). Gerçekten de yeryüzü tüm insanlığın ortak mirasıdır. Dolayısıyla parasını verenin, dilediği EH'ni dilediği düzeyde istismar etmesi kabul edilemez.

\section{Orman fonksiyonu ve orman ekosistem hizmeti arasındaki farklılıklar}

Ormanların sunduğu çeşitli fonksiyon, hizmet ve faydaların hepsi ülkemizde OF olarak anılsa da, OF ve EH arasında önemli farklılıklar vardır. Bu farklılıklar yalnızca terminolojik değil, aynı zamanda kavramsaldır. Farkın net olarak anlaşılabilmesi için, bir önceki bölümde orman ekosistemine uyarlanan basamaklı modelin iyi kavranması gerekir. Şekil 2'de görüldüğü gibi OF ve EH, orman ekosistemi'nin iki ayrı bileşenidir. Burada OF; bir ormanın ilgili EH'ni sağlayabilmesi için gereksinim duyduğu kapasite olarak algılanmalıdır. Söz konusu kapasite, ormanın potansiyeline işaret eder (örn. yüksek ağaç serveti=yüksek odun üretim potansiyeli gibi). Orman EH ise; ormanın fonksiyonlarından türetilirler ve gerçek hayatta insanlara fiili bir hizmet akışı sunarlar. İnsanlar bu hizmetlerden farkında olarak veya olmayarak fayda sağlarlar (Şekil 2). Bu bağlamda orman EH; OF'nun insanlar tarafindan kullanılan kısmı (örn. odun üretimi için eta miktarı) ve böylelikle ormanın insanoğluna sağladığı katkılardır, şeklinde tanımlanabilir.

Örneklendirmek gerekirse; araçla ya da yaya olarak ulaşımı çok zor olan bir orman arazisinde rekreasyonel kullanıma oldukça uygun meşcereler bulunabilir. Buralarda ormanın rekreasyon fonksiyonu üst düzeyde sağlanıyordur. Ancak insanların bu alandan haberi olmadığı ya da haberi olsa bile ulaşamadıkları için OF, EH'ne dönüşememektedir. Diğer bir ifadeyle; orman ekosisteminin bu alandaki kapasitesinden insanlar çeşitli nedenlerle faydalan(a)mamaktadırlar. $\mathrm{Bu}$ anlamda, Belgrad Ormanları'nın sunduğu üst düzey rekreasyon EH, ormandaki rekreasyonel olanaklar kadar, alanın İstanbul gibi çok kalabalık bir şehirde yer almasından da kaynaklanmaktadır.
Aynı orman, örneğin Artvin'de bulunmuş olsaydı, rekreasyon fonksiyonu aynı olmasına rağmen rekreasyon $\mathrm{EH}$ muhtemelen çok daha alt düzeylerde temin edilebilirdi. Nitekim, Artvin'deki Kafkasör Kent Ormanı, tıpkı Belgrad Ormanları gibi -belki de daha fazla- olanaklar sunsa da, yıllık ziyaretçi sayısı çok daha azdır.

Benzer bir örnek, mutlak korumaya ayrılmış milli parklar için de verilebilir. Milli park içindeki ormanlar teorik olarak odun üretimi fonksiyonunu yerine getirebilmelerine rağmen, buralarda $\quad$-genellikle- ${ }^{-}$üretim faaliyetleri gerçekleştirilmediği için, odun üretimi $\mathrm{EH}$ akış1 olmamaktadır. Yani pratikte milli parkların odun üretimi $\mathrm{EH}$ potansiyelinden değil, diğer potansiyellerinden (biyoçeşitlilik, rekreasyon, yaban hayatı, estetik görünüm vd.) faydalanılmaktadır.

Yukarıdaki örneklerden anlaşıldığı gibi OF ve EH kavramları, insanoğlu ve doğa arasındaki etkileşimin farklı boyutlarını ön plana çıkarmaktadırlar. Bu farklılık, doğal olarak tematik haritalara da yansımaktadır. OF ve EH düzeyleri hem zamansal hem de konumsal olarak örtüşmedikleri için, aynı ormanın OF ile EH haritaları çoğunlukla birbirinden farklıdır. Schulp vd. (2012), Doğu Avrupa'daki ülkelerin birçok EH ve OF'nu haritalamışlardır. Aynı temaya sahip (örn. ODOÜ) haritalar üst üste çakıştırıldıklarında, EH ve OF arasındaki konumsal uyuşmazlıklar oldukça belirgindir. Araştırmacılar, yüksek OF düzeylerinin genellikle homojen yapıdaki doğal alanlarda yoğunlaştı̆̆ını bildirmişlerdir. EH sıcak noktaları ise doğallık ve insan kullanımının içiçe geçtiği heterojen yapıdaki arazilerde toplanmıştır.

OF ve EH arasındaki bir diğer farklılık; sınıflandırma sistemlerinde görülmektedir. Ek Çizelge 1-2'den anlaşıldığ gibi, EH yaklaşımı hiyerarşik ve daha ayrıntılı bir sınıflandırma sunmaktadır. Bunun nedeni, bazı EH için farkında olmadan yapılabilen mükerrer sayımların önüne geçmektir (Hansen ve Malmaeus, 2016). Aksi takdirde doğal sermaye, olduğundan daha değerliymiş gibi gösterilmiş olur. İki yaklaşımın kronolojisi göz önüne alındığında, bu durum doğal karşılanmalıdır. Nitekim, OF yaklaşımının ortaya çıkışı, EH'ne göre çok daha eskiye dayanmaktadır. Ancak, ülkemizdeki OF sınıflandırma sisteminde bir takım mantıksal tutarsızlıklar da söz konusudur. Örneğin; "Hidrolojik Fonksiyon", sosyokültürel OF grubunda yer almaktadır (Ek Çizelge 1). Halbuki orman ekosisteminin biyofiziksel yapısı ve içindeki biyokimyasal süreçler marifetiyle su rejimini düzenlemesi ekolojik bir hadisedir. Dolayısıyla OGM (2017)'deki Hidrolojik Fonksiyon, sosyokültürel OF grubundan çıkarılarak ekolojik OF grubuna sokulmalıdır. Şayet Hidrolojik Fonksiyon'dan kasıt içme ve kullanma suyu üretimi ise bu sefer de ekonomik OF (1118) söz konusu olur (Ek Çizelge 1). Bu noktada Hidrolojik Fonksiyon ile ilgili çarpıcı bir örnekten söz etmek yerinde olur. Bilindiği gibi, insanoğlunun erişebildiği tatlı su kaynaklarının büyük bir kısmı (\%75'i) ormanlık havzalardan sağlanmaktadır (MEA, 2005). Fakat ülkemizde kullanılan şebeke suyu ücretlerinin tamamı, haneler tarafından genellikle belediyelere bağlı sular idaresine ödenmektedir. Toplanan bu ücretlerden orman teşkilatına ayrılan bir pay bulunmamaktadır. Yani su, "serbest mal" olarak değerlendirilmektedir. Oysa ki; kaliteli suyun ormanlardan düzenli temininin OGM'ye bir takım maliyetleri vardır (örn. uzun idare süresi, sıklık bakımı vd.) (Eker, 2018). Bunun yanı sıra, söz konusu orman alanları amenajman planlarında hidrolojik fonksiyona ayrılarak odun 
üretimi, toprak korunması ve diğer birçok EH'nden feragat edilmektedir. OGM tarafindan katlanılan bu maliyetlerin parasal karşılığının farklı kurumlar tarafından tahsil edilmesi çelişkili bir durumdur ve kurumsal düzeyde tartışılmalıdır.

OF ve EH kavramları arasındaki farklılıklar kavrandıkça, özellikle orman amenajmanı disiplininde sıklıkla kullanılan "işletme amacı" kavramı akla gelebilir. Eraslan ve Şad (1993)'te de belirtildiği gibi, orman ekosisteminde kendiliğinden ortaya çıkan bir fonksiyona, toplum tarafından talep oluşması halinde, o fonksiyon ormanın ișletme amacı (ya da koruma hedefi) olur. Ancak, orman amenajmanı bakış açısıyla yapılan bu tanımlamaya dayanarak, işletme amacı ile EH arasında benzerlik kurmak yanıltıcı olacaktır. Çünkü özellikle ekolojik OF'nın birçoğuna toplum tarafından aktüel talep olmamaktadır. Örneğin; ülkemizdeki ormanlık bir havzanın alt kesiminde ya da dere yatağındaki yerleşim yerlerinde ikamet eden insanların, üst havzadaki ormanın su rejimini düzenleme veya sel/taşkınları önleme fonksiyonuyla ilgili somut bir talebi genellikle söz konusu değildir. Hatta hane halkı çoğu zaman bu koruyucu etkinin farkında bile değildir (örtülü EH). Fakat buradaki ormancılık faaliyetleri (aralama şiddeti, tıraşlama kesim, maktaların büyüklügü ve konumsal dağılımı vs.), hane halkının can güvenliği ve refah düzeyini önemli ölçüde etkilemektedir.

$\mathrm{OF}$ ve EH terimlerinin literatürde birbirlerinin yerine kullanıldıkları da görülmektedir. Örneğin; OGM (2017)'deki "Orman Fonksiyonları, İşletme Amaçları ve Koruma Hedefleri Tablosu"nda erozyonu önleme; OF, toprak koruma (2213) ise; koruma hedefi olarak yer almaktadır (Ek Çizelge 1). Halbuki; ormanın tepe tacı, kök ve diğer biyofiziksel özellikleriyle toprağı aşınmaya karşı koruması OF iken, bu sayede toprak erozyonunun önlenmesi EH'dir. Benzer şekilde, ormanların su rejimini düzenleme gibi çok önemli bir fonksiyonu bulunmaktadır. $\mathrm{Bu}$ OF sayesinde, sel ve taşkınların kontrol edilmesi ise EH'dir. Buna ilaveten, iklimin düzenlenmesi OF; temiz hava temini, atmosferdeki sera gazı birikiminin azaltılması, küresel iklim değişikliğinin yavaşlatılması vd. EH'dir. Dolayısıyla, terim ve kavramlar birbirine karıştırılmamalıdır. Elbette bu kafa karışıklığ yalnızca bizim ülkemizde yaşanmamaktadır. Yurtdışındaki ormancılar da OF (function), ormanın görevi (forest's task), kullanımı (forest use), değeri (forest value), katkısı (forest's contribution), hizmeti (forest's service) ve doğal etkisi (natural effect) terimlerini sıklıkla eşanlamlıymış gibi kullanmakta ve EH yaklaşımıyla SOY'ni zaman zaman birbirine karıştırmaktadırlar (Jax, 2005; Bader ve Riegert, 2011; Quine vd., 2013).

Terminolojik farklılıkların haricinde, $\mathrm{OF}$ ve $\mathrm{EH}$ yaklaşımları (konseptler) arasında da önemli farklılıklar bulunmaktadır. Örneğin; OF yaklaşımı ekosistemde doğal olarak oluşan arz konusunu kapsamaktadır. EH yaklaşımı ise; hem arz hem aktüel akış hem de toplum tarafından talep edilen fayda düzeyleriyle ilgilenmektedir (Şekil 2). OF ve EH yaklaşımları arasındaki diğer farklılıklar Çizelge 2'de özet olarak sunulmuştur.

\section{Sonuç ve öneriler}

Bu çalışmada OF ve EH kavramları ilk önce birbirinden bağımsız olarak ele alınmış, devamında aralarındaki bağlantı orman ekosistemine uyarlanmış basamaklı model (Şekil 2) yardımıyla kurulmuş ve daha sonra her iki yaklaşım birbiriyle karşılaştırılmıştır. Çalışmanın sonunda; OF ve orman EH'nin hem terimsel hem de kavramsal olarak birbirinden farklı yaklaşımlar olduğu ve birbirleriyle karıştırıldıkları takdirde karar vericileri yanıltabileceği sonucuna ulaşılmıştır. Ayrıca EH yaklaşımının OF yaklaşımına tercih edilmesinin günümüzdeki modern ormancılık anlayışına daha uygun olacağı anlaşılmıştır. Çünkü OF yaklaşımı yalnızca ormanın doğal yapısı (kuruluşu) ve kapasitesi (potansiyeli) ile ilgilenirken, EH yaklaşımı daha bütüncül yapısıyla insanların ormandan talep ettiği fayda ve maddi/manevi değerleri de (toplum refahı) dikkate almaktadır.

Çizelge 2. OF ve EH yaklaşımları arasındaki farklılıklar (Pistorius vd., 2012; Kindler, 2016; Tiemann ve Ring, 2018; Boncina vd., 2019)

\begin{tabular}{lll}
\hline & Orman fonksiyonları & Ekosistem hizmetleri \\
\hline Köken & Almanya (1950’ler) & ABD ve tüm dünya (2000’ler) \\
Bakış açısı & Devlet merkezci & İnsan merkezli, liberal \\
Ana amaç & Ekonomik, ekolojik ve sosyokültürel fonk. dengeleyen çok & $\begin{array}{l}\text { Biyoçeşitliliği korumak, tekil ekosistem hizmetlerinin } \\
\text { devaml temini }\end{array}$ \\
& amaçlı ormancıllk & Multidisipliner \\
Bilim dalı & Dar ormancıllk & Doğal kaynak planlamacıları, politika yapıcılar, iş dünyası \\
Hedef kitle & Ormancılar, bölgesel planlamacılar & Ekosistemler ve doğal sermayenin önemini kavratmak \\
Temel motivasyon & Orman sahibini tatmin etmek, toplum ihtiyaçlarını karşılama & Tüm ekosistemler, toplum refahı, eko- ve sosyo-ekonomik \\
İlgi alanı & Orman ekosisteminin bizatihi kendisi & sistem arasındaki bağlar \\
& & Ulusal ve uluslararası sözleşme ve girişimler üzerinden \\
\hline
\end{tabular}


Türkiye ormancılığında EH yaklaşımının benimsenmesi halinde birçok avantaj sağlanabileceği gibi, OF uygulamasının (ETFOP) hali hazırdaki bir takım eksiklikleri de giderilmiş olacaktır. Bu anlamda, EH yaklaşımının bizlere sunduğu bazı olanakları sıralamak mümkündür;

- Sayısallaştırma, modelleme ve ekonomik değer takdiri için gerekli olan göstergelerin (indikatör) birçoğu, uluslararası EH literatüründe mevcuttur (Çizelge 1). İlgili göstergeler, olduğu gibi ya da Türkiye şartlarına uyarlanarak kullanılabilir.

- Tekil OF için optimal orman yapıları ve her bir meşcere tipinin ilgili OF'nun teminine katkısı (performansı) sayısal olarak belirlenebilir.

- Birbiriyle uyuşan ve çelişen orman işletme amaçları netlik kazanır. Farklı amaçlar arasındaki ahenk ve ödünleşimler kantitatif analizlerle ortaya konabilir. Böylelikle, tekil EH çok daha etkili bir şekilde eniyilenebilir (optimizasyon).

- Ormanın aktüel yapısı ve EH arzının geleceğe dönük uzun vadeli kestirimini yapabilen bilimsel karar verme teknikleri (karar destek sistemleri) için altlık modeller daha kolay sağlanır. Böylelikle planlamacılar, sezgisel ve öznel kararlar almak zorunda kalmazlar.

- Orman kaynaklarının uzun vadeli (100-200 yıl gibi) planlanması, ülkemizde taktik düzeyde (10-20 y1llık) hazırlanan orman amenajman planlarına stratejik bir boyut katar.

- EH yaklaşımı yalnızca ormancılık disipliniyle sınırlı olmadığından Orman İşletme Şefliği dahilinde kalan diğer arazi kullanımlarının da (mera, ziraat, sulak alan) planlaması bütüncül bir şekilde gerçekleşir. Böylelikle havza bazlı veya farklı sektörlerle işbirliği içerisinde entegre amenajman planları daha rahat hazırlanabilir.

- Ormanların sunduğu ekonomik, ekolojik ve sosyokültürel kaynaklar daha eşitlikçi bir anlayışla dengelenebilir. Böylece orman işletmelerinin hala ağırlıklı olarak odun üretimi eksenli ormancılık yaptığı yönündeki itirazlar azaltılır.

- Piyasada değerlendirilebilen orman ürünleri haricindeki diğer EH'ne de parasal değer takdir edilebilmesi yolunda çok önemli bir adım atılmış olur. Yurtdışında hayli yaygın olan "EH için ücret ödeme" mekanizmaları (PES, $W T P$ ) gündeme gelir. Böylelikle orman kaynaklarının yönetimi için ilave kamu kaynağı sağlanabilir.

- Doğal sermaye (natural capital) hakkında farkındalık yaratılır. Orman teşkilatının halkla kurduğu ilişkiler daha da güçlenir, katılımcı yaklaşımlar artar.

EH, hem Türkiye genelinde hem de ormancılık sektörü özelinde nispeten yeni bir yaklaşımdır. Dünyada hızla benimsenen bu yaklaşımın, yakın gelecekte ülkemizde de kendine geniş kullanım alanı bulacağı tahmin edilmektedir. Kullanım alanları yaygınlaştıkça, uygulamada yaşanabilecek sorunların çıkması da kaçınılmazdır. İleride yaşanabilecek sorunların önüne geçmek için araştırmacılara aşağıdaki önerilerde bulunulabilir;

- OF (Ek Çizelge 1) ve orman EH (Ek Çizelge 2) tabloları birbirine bağlanarak hangi OF'nun hangi EH ya da EH gruplarına karşılık geldiği netleştirilmelidir.

- Üzerinde çok çalışılmamış bazı EH için Türkiye şartlarına özgü kantitatif göstergeler geliştirilmelidir (örn. kötü kokuların önlenmesi, kültürel miras, manevi etkileşimler vd.).

- Orman İşletme Şeflikleri tarafindan sunulan odun üretimi, rekreasyon vd. olanakların, $\mathrm{OF}$ ve EH haritaları ayrı ayrı üretilerek aradaki konumsal ve zamansal farklılıklar ortaya konmalıdır.

- Tekil EH haritaları, kendi içerisinde arz, talep ve fiili akış (mobilizasyon) olarak ayrı ayrı üretilmelidir.

- Aynı şefliğin çeşitli EH'ne ait haritaları üst üste çakıştırılarak toplam EH düzeyinin çok yüksek olduğu alanlar (EH sicak noktaları) belirlenmeli ve buralarda özel koruma önlemleri alınmalıdır.

Sıralanan bu önerilerin ülkemizde hayata geçirilebilmesi için atılabilecek ilk ve en etkin adım; EH'nin orman amenajman planlarına entegrasyonu konusunun resmen ve kurumsal olarak benimsenmesi olacaktır.

\section{Kaynaklar}

6831 sayılı O.K., 1956. 6831 sayılı Orman Kanunu. Resmi gazetede yayınlandığı tarih: 8 Eylül 1956, $33 \mathrm{~s}$.

Asan, Ü., Şengönül, K., 1988. Orman formlarının fonksiyonel açıdan karşılaştırılması. İstanbul Üniversitesi Orman Fakültesi Dergisi, 4(B): 52-67.

Asan, Ü., 1990. Orman kaynaklarının çok amaçlı kullanımı ve fonksiyonel planlama. İstanbul Üniversitesi Orman Fakültesi Dergisi, 40(3): 67-84.

Asan, Ü., 2013. Orman Amenajmanı Esasları - Temel Kavramlar, Amaçlar ve İlkeler. İstanbul Üniversitesi Yayınları, İstanbul.

Asan, Ü., 2017. Orman Amenajmanı (Planlama Sistemleri). İstanbul Üniversitesi Yayınları, İstanbul.

Bader, A., Rieger, C., 2011. Interdisciplinarity in $19^{\text {th }}$ and early $20^{\text {th }}$ century: Reflections on ecosystem services of forest. Rupkatha Journal on Interdisciplinarity Studies in Humanities, 3(1): 8798.

Başkent, E.Z., Başkaya, Ş., Terzioğlu, S., 2008. Developing and implementing participatory and ecosystem based multiple use forest management planning approach (ETÇAP): Yalnız̧̧am case study. Forest Ecology and Management, 256: 798-807.

Başkent, E.Z., Keleş, S., Mumcu Küçüker, D., 2013. Ülkemiz ormanlarının karar destek sistemleri/modelleme ile planlanması sürecinin analizi. Ormancilıkta Sektörel Planlamanın 50. Y1lı Uluslararası Sempozyumu Bildiriler Kitab1, 26-28 Kasım, Antalya, s. 69-79.

Başkent, E.Z., 2018. A review of the development of the multiple use forest management planning concept. International Forestry Review, 20(3): 296-313.

Başkent, E.Z., 2020. A framework for characterizing and regulating ecosystem services in a management planning context. Forests, 11: 102 .

Boerema, A., Rebelo, A.J., Bodi, M.B., Esler, K.J. Meire, P., 2017. Are ecosystem services adequately quantified? Journal of Applied Ecology, 54: 358-370.

Boncina, A., Simoncic, T., Rosset, C., 2019. Assessment of the concept of forest functions in Central European forestry. Environmental Science and Policy, 99: 123-135.

Burkhard, B., Kroll, F., Müller, F., Windhorst, W., 2009. Landscapes' capacities to provide ecosystem services - a concept for land-cover based assessment. Landscape Online, 15: $1-22$.

Burkhard, B., Kandziora, M., Hou, Y., Müller, F., 2014. Ecosystem service potentials, flows and demands - concepts for spatial localization, indication and quantification. Landscape Online, 34: $1-32$.

Burkhard, B., Maes, J., 2017. Mapping Ecosystem Services. Pensoft Publishers, Sofya. 
Costanza, R., d'Arge, R., de Groot, R., Stephen F., Grasso, M., Hannon, B., Limburg, K., Naeem, S., O’Neill, R., V., Paruelo, J., Raskin, R.G., Sutton, P., van den Belt, M., 1997. The value of the world's ecosystem services and natural capital. Nature, 387: 253-260.

Çağlar, Y., 2011. Çevreleme (1. bask1). İmge Kitabevi, Ankara.

Çolak, A.H., Kırca, S., Rotherham, I.D., İnce, A., 2010. Restoration and Rehabilitation of Deforested and Degraded Forest Landscapes in Turkey. Çevre ve Orman Bakanlığı, Ağaçlandırma ve Erozyon Kontrolü Genel Müdürlüğü Yayınları, Ankara.

Daily, G., 1997. Nature's Services: Societal Dependence on Natural Ecosystems. Island Press, Washington DC.

de Groot R.S., 1992. Functions of Nature - Evaluation of Nature in Environmental Planning, Management and Decision Making. Wolters-Noordhoff, Amsterdam.

de Groot, R.S., Wilson, M.A., Boumans, R.M.J., 2002. A typology for the classification, description and valuation of ecosystem functions, goods and services. Ecological Economics, 41: 393408.

de Groot, R.S., Alkemade, R., Braat, L., Hein, L., Willemen, L., 2010. Challenges in integrating the concept of ecosystem services and values in landscape planning, management and decision making. Ecological Complexity, 7: 260-272.

Dieterich, V., 1953. Forstwirtschaftspolitik - Eine Einführung. Paul Parey, Hamburg ve Berlin.

Dunford, R.W., Harrison, P.A., Bagstad, K.J., 2017. Computer modelling for ecosystem service assessment. In: Mapping Ecosystem Services (Ed: Burkhard, B., Maes, J.), Pensoft Publishing, Sofya, pp. 124-135.

Durkaya, A., Birsen, D., Kaptan, S., 2013. ETFOP sisteminde sosyoekonomik, -kültürel durum envanteri ve katılımcılık süreci ile entegre edilmesi. Ormancılıkta Sektörel Planlamanın 50. Y1lı Uluslararası Sempozyumu Bildiriler Kitabı, 26-28 Kasım, Antalya, s. 339-351.

Egoh, B., Drakou, E.G., Dunbar, M.B., Maes, J., Willemen, L., 2012. Indicators for mapping ecosystem services: a review. Technical report, JRC Scientific and Policy Reports, Publications Office of the EU, Luxemburg.

Eker, Ö., 2018. Ekosistem hizmet ödemelerinin odun dişı orman ürün ve hizmetleri kapsamında değerlendirilmesi: Su ve su kaynakları yönetimi. Turkish Journal of Forest Science, 2(2): 165-176.

Eraslan, İ., Şad, H.C., 1993. Orman Amenajmanı. İstanbul Üniversitesi Yayınları, İstanbul.

Eraslan, İ., Eler, Ü., 2014. Orman İşletmesinin Planlanması ve Denetimi. Süleyman Demirel Üniversitesi Yayınları, Isparta.

European Commission, 2011. Our Life Insurance, Our Natural Capital: An EU Biodiversity Strategy to 2020. European Commission, Publications Office of the European Union, Luxembourg.

Frank, S., Fürst, C., Witt, A., Koschke, L., Makeschin, F., 2014. Making use of the ecosystem services concept in regional planning - trade-offs from reducing water erosion. Landscape Ecology, 29: 1377-1391

Gadow K.V., Nagel, J., Saborowski, J., 2002. Continuous Cover Forestry. Springer, Netherlands.

Gómez-Baggethun, E., de Groot, R., Lomas, P.L., Montes, C., 2010. The history of ecosystem services in economic theory and practice: From early notions tomarkets and payment schemes. Ecological Economics, 69: 1209-1218.

Gret-Regamey, A., Weibel, B., Kienast, F., Rabe, S-E., Zulian, G., 2015. A tiered approach for ecosystem services mapping. Ecosystem Services, 13: 16-27.

Güngör, E., 2010. Orman kaynaklarının bütünleşik ișlevsel yönetim planlamasi. Doktora tezi, Bartın Üniversitesi Fen Bilimleri Enstitüsü, Bartın.

Haines-Young, R., Potschin, M.B., 2018. Common International Classification of Ecosystem Services (CICES) V5.1 and Guidance on the Application of the Revised Structure.
Hanewinkel, M., 2011. Multifunktionalitat des Waldes. Forum für Wissen, 7-14.

Hansen, K., Malmaeus, M., 2016. Ecosystem services in Swedish forests. Scandinavian Journal of Forest Research, 31(6): 626640

Hasel, K., 1971. Waldwirtschaft und Umwelt: Eine Einführung in die Forstwirtschaftspolitischen Probleme der Industriegesellschaft. Paul Parey, Hamburg.

Hauck, J., Schweppe-Kraft, B., Albert, C., Görg, C., Jaxi, K., Jenson, R., 2013. The promise of the ecosystem services concept for planning and decision making. GAIA, 22(4): 232-236.

Henne, A., 1974. Vorwort. In: Leitfaden zur Kartierung der Schutzund Erholungsfunktionen des Waldes (Waldfunktionenkartierung) WFK, Arbeitskreis Zustandserfassung und Planung der Arbeitsgemeinschaft Forsteinrichtung Arbeitsgruppe Landespflege (Ed. Sauerländer, J.D.), Verlag, Frankfurt.

IPBES, 2018. The IPBES regional assessment report on biodiversity and ecosystem services for Europe and Central Asia. In: Secretariat of the Intergovernmental Science-Policy Platform on Biodiversity and Ecosystem Services (Ed: Rounsevell, M., Fischer, M., Torre- Marin Rando, A., Mader, A.), Bonn, pp. 148.

Jax, K., 2015. Function and functioning in ecology: What does it mean? OIKOS, 111: 3 .

Kapucu, F., 2004. Orman Amenajmanı. Karadeniz Teknik Üniversitesi Yayınları, Trabzon.

Karahalil, U., Keleş, S., Başkent, E.Z., Köse, S., 2009. Integrating soil conservation, water production and timber production values in forest management planning using linear programming. African Journal of Agriculture Research, 4(11): 1241-1250.

Keleş, S., Durusoy, I., Çakir, G., 2017. Analysis of the changes in forest ecosystem functions, structure and composition in the Black Sea region of Turkey. Journal of Forestry Research, 28(2): 329-342.

Kindler, E., 2016. A comparison of the concepts: Ecosystem services and forest functions to improve interdisciplinary exchange. Forest Policy and Economics, 67: 52-59

Kose, S., Baskent, E.Z., 1997. Thirty year history of even-aged management. Journal of Sustainable Forestry, 5(3-4): 15-26.

MAES, 2011. Mapping and Assessment of Ecosystems and their Services. http://biodiversity.europa.eu/maes Accessed: 02.07.2020

Maes, J., Teller, A., Erhard, M., Grizzetti, B., Barredo, J.I., Paracchini, M.L., Condé, S., Somma, F., Orgiazzi, A., Jones, A., Zulian, A., Vallecilo, S., Petersen, J.E., Marquardt, D., Kovacevic, V., Abdul Malak, D., Marin, A.I., Czúcz, B., Mauri, A., Loffler, P., BastrupBirk, A., Biala, K., Christiansen, T., Werner, B., 2018. Mapping and Assessment of Ecosystems and Their Services: An Analytical Framework for Ecosystem Condition. Publications office of the European Union, Luxembourg.

MEA, 2005. Millennium Ecosystem Assessment - Ecosystems and Human Well-being: Synthesis. Island Press, Washington, DC.

Moreau de Jonnès, M.A., 1825. In: Premier mémoire en réponse à la question proposée par l'Académie royale de Bruxelles: quels sont les changemens que peut occasioner le déboisement de forêts considérables sur les contrées et communes adjacentes et en général à tout ce qui constitue son état physique actuel? (Ed. Bruxelles de Mat, P.J.), Imprimeur de l'Académie royale de Bruxelles, Brüksel.

Mutlu, B.E., Cengiz, B., 2017. Uzman perspektifinden Bolu Kent Ormanı'nın çok fonksiyonlu kullanım özelliklerinin değerlendirilmesi üzerine bir araştırma. Iğdır Üniversitesi Fen Bilimleri Enstitüsü Dergisi, 7(4): 213-222.

OGM, 2008. Orman Amenajman Yönetmeliği. Orman Genel Müdürlüğü, Orman İdaresi ve Planlama Dairesi Başkanlığı, Ankara. 
OGM, 2010. Altıparmak Orman İşletme Şefliği Ekosistem Tabanlı Fonksiyonel Amenajman Planı (2010-2039). Orman Genel Müdürlüğü, Ankara.

OGM, 2012. Ekosistem Tabanlı Fonksiyonel Orman Amenajman Planlarının Uygulanmasına ait Usul ve Esaslar (295 sayılı tebliğ ). Orman Genel Müdürlüğü, Ankara.

OGM, 2015. Ekosistem Tabanlı Fonksiyonel Orman Amenajman Planlarının Düzenlenmesinin Denetimine Ait Usul ve Esaslar (Tebliğ No: 301). Orman Genel Müdürlüğü, Ankara.

OGM, 2017. Ekosistem Tabanlı Fonksiyonel Orman Amenajman Planlarının Düzenlenmesine Ait Usul ve Esaslar (299 sayılı tebliğ-düzeltmeli son bask1), Orman İdaresi ve Planlama Dairesi Başkanlığı, Ankara.

OGM, 2020. Sürdürülebilir Orman Yönetimi Kriter ve Göstergeleri 2019 Türkiye Raporu. Strateji Geliştirme Dairesi Başkanlığı, Orman Genel Müdürlüğü, Ankara.

Özdemir, M., Serengil, Y., Yurtseven, İ., Muhittin, İ., Pamukçu Albers, P., Tonbul, C., 2020. Ormanların su üretim hizmetine yönelik yeni planlama yaklaşımı. Ormancılık Araştırma Dergisi, 7(2): 162-178

Pistorius, T., Schaich, H., Winkel, G., Plieninger, T., Bieling, C., Konold, W., Volz, K.R., 2012. Lessons for REDDplus: A comparative analysis of the German discourse on functions and the global ecosystem services debate. Forest Policy and Economics, 18: 4-12.

Potschin, M.B., Haines-Young, R.H., 2011. Ecosystem services: Exploring a geographical perspective. Progress in Physical Geography, 35(5): 575-594

Quine, C.P., Bailey, S.A., Watts, K., 2013. Sustainable forest management in a time of ecosystem services frameworks: Common ground and consequences. Journal of Applied Ecology, 50: 863-867.

Resolution H1, 1993. General guidelines for the sustainable management of forests in Europe. Second Ministerial Conference on the Protection of Forests in Europe, 16-17 Haziran, Helsinki.

Saraçoğlu, N., 2010. Küresel İklim Değişimi, Biyoenerji ve Enerji Ormancılı̆̆ı. Efil Yayınları, Ankara.

Saastamoinen, O., Matero, J., Horne, P., Kniivilä, M., Haltia, E., Vaara, M., Mannerkoski, H., 2014. Classification of boreal forest ecosystem goods and services in Finland. Publications of the University of Eastern Finland Reports and Studies in Forestry and Natural Sciences, No. 11, Joensuu.

Sağkaya, A., 2020. Ormanc1 (1. Bask1). Önder Matbaacılı, Ankara.

Schulp, C.J.E., Alkemade, R., Goldewijk, K.K., Petz, K., 2012. Mapping ecosystem functions and services in Eastern Europe using global-scale data sets. International Journal of Biodiversity Science, Ecosystem Services \& Management, 8(12): $156-168$

Sing, L., Ray, D., Watts, K., 2015. Ecosystem services and forest management. Forestry Commission, General Technical Report, Edinburgh.

Syrbe, R.U., Schröter, M., Grunewald, K., Walz, U., Burkhard, B., 2017. What to map? In: Mapping Ecosystem Services (Ed: Burkhard, B., Maes, J.), Pensoft Publishing, Sofya, pp. 149-156.

Şengönül, K., Şahin, A., 2017. Toprak koruma fonksiyonlu ormanların ayrılma kriterleri ve amaç kuruluşlarının belirlenmesi esasları. 2023'e Doğru 4. Doğa ve Ormancılık Sempozyumu, 3-6 Aralık, Antalya, s. 429-449.
TEEB, 2011. The Economics of Ecosystems and Biodiversity in National and International Policy Making (Ed: Brink, P.T.), Earthscan, Londra ve Washington.

Tezer, A., Turkay, Z., Uzun, O., Terzi, F., Koylu, P., Karacor, E., Okay, N., Kaya, M., 2018. Ecosystem services-based multicriteria assessment for ecologically sensitive watershed management. Environment, Development and Sustainability, 22: 2431-2450 DOI: $10.1007 / \mathrm{s} 10668-018-00300-5$

Tiemann, A., Ring, I., 2018. Challenges and opportunities of aligning forest function mapping and the ecosystem service concept in Germany. Forests, 9: 691

UNCED, 1992. Birleşmiş Milletler Çevre ve Kalkınma Konferansı Raporu. Ek 3: Ormancılık İlkeleri, Birleşmiş Milletler, New York.

Uygur, B., 2016. Hidrolojik ekosistem hizmetlerinin havza planlamaya uyarlanması. Doktora tezi, İstanbul Üniversitesi Fen Bilimleri Enstitüsü, İstanbul.

Uygur Erdoğan, B., 2017. Regulation and mitigation services of forests as the components of urban resilience. European Water, 59: 395-401.

Üzenge, E., 2013. Orman amenajmanında yaş sınıfları metodunun uygulanması, karşılaşılan problemler ve çözüm önerileri. Ormancılıkta Sektörel Planlamanın 50. Y1lı Uluslararası Sempozyumu Bildiriler Kitabı, 26-28 Kasım, Antalya, s. 120131.

Vatandaşlar, C., 2020. Orman ekosistemlerinin erozyonu önleme fonksiyonunun amenajman planlama sürecine entegrasyonu. Doktora tezi, Artvin Çoruh Üniversitesi Lisansüstü Eğitim Enstitüsü, Artvin.

Vatandaşlar, C., Yavuz, M., Leuchner, M., 2020. Erosion control service of forest ecosystems: A case study from Northeastern Turkey. In: Smart Geography (Ed: Nedkov, S.), Springer International Publishing, Switzerland, pp. 443-455.

Vihervaara, P., Mononen, L., Santos, F., Adamescu, M., Cazacu, C., Luque, S., Geneletti, D., Maes, J., 2017. Biophysical quantification. In: Mapping Ecosystem Services (Ed: Burkhard, B., Maes, J.), Pensoft Publishers, Sofya, pp. 93-101.

Yılmaz, E., 2004. Ülkemizdeki orman işlevleri ve tahsis kriterleri. Doğu Akdeniz Ormancılık Araştırma Müdürlüğü DOA Dergisi, 10: 1-25.

Yılmaz, E., 2013. Orman kaynakları planlamasında katılımc yaklaşımlar: Uygulama örnekleri ve kazanılan deneyimler. Ormancılıkta Sektörel Planlamanın 50. Y1lı Uluslararası Sempozyumu Bildiriler Kitabı, 26-28 Kasım, Antalya, s. 178187.

Yüksel, İ., Koçer, M., Doğan, S.A., 2013. Gölyaka Orman İşletme Müdürlüğü'nde orman fonksiyonlarının yıllar itibariyle değişimi. Ormancılıkta Sektörel Planlamanın 50. Y1l Uluslararası Sempozyumu Bildiriler Kitabı, 26-28 Kasım, Antalya, s. 365-376.

Zengin, H., Yeşil, A., Asan, Ü., Bettinger, P., Cieszewski, C., Siry, J.P., 2013. Evolution of modern forest management planning in the Republic of Turkey. Journal of Forestry, 111(4): 239-248.

Zwierlein, K.A., 1806. Vom großen Einfluss der Waldungen auf Kultur und Beglückung der Staaten mit besonderer Hinsicht auf Polizei, Würzburg. 
Ek Çizelge 1. Türkiye'de orman fonksiyonlarının sınıflandırılması (OGM, 2017; Eraslan ve Şad, 1993)

\begin{tabular}{|c|c|c|c|}
\hline Ana grup & Genel orman fonksiyonu & İşletme amacı & $\begin{array}{l}\text { Amenajman planı sayısal veri } \\
\text { tabanlarındaki kodu }\end{array}$ \\
\hline \multirow{11}{*}{ 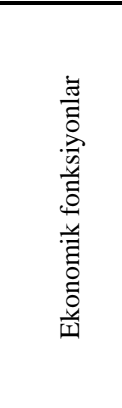 } & \multirow{11}{*}{ Orman ürünleri üretimi } & En yüksek miktarda end. odun üretimi (End. ağaçlandırma) & $1109+$ Ağaç türü kodu \\
\hline & & Kaliteli ve özellikli odun üretimi & $1110+$ Ağaç türü kodu \\
\hline & & En yüksek miktarda yapacak odun üretimi & $1111+$ Ağaç türü kodu \\
\hline & & Yakacak odun üretimi & 1112 + Ağaç türü kodu \\
\hline & & Özel ağaçlandırma & 1113 + Ağaç türü kodu \\
\hline & & Odun dışı orman ürünleri üretimi & 1114 + Ağaç türü kodu \\
\hline & & Basralı alanlar ve bal üretim ormanları & 1115 + Ağaç türü kodu \\
\hline & & Bitkisel ürünler & 1116 + Ağaç türü kodu \\
\hline & & Hayvansal ürünler & 1117 + Ağaç türü kodu \\
\hline & & Su ve mineral ürünler & 1118 + Ağaç türü kodu \\
\hline & & Otlatma alanları & 1119 + Ağaç türü kodu \\
\hline \multirow{26}{*}{ 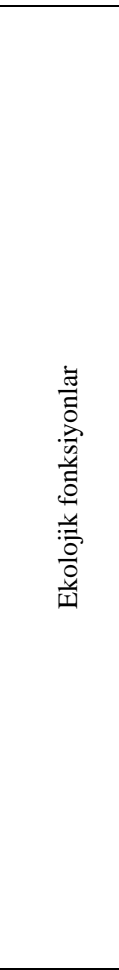 } & \multirow{20}{*}{ Doğayı koruma } & Doğayı koruma & 2100 + Ağaç türü kodu \\
\hline & & Gen koruma ormanı & 2110 + Ağaç türü kodu \\
\hline & & Milli parklar & $2111+$ Ağaç türü kodu \\
\hline & & Muhafaza ormanı & 2112 + Ağaç türü kodu \\
\hline & & Tabiat park1 & 2113 + Ağaç türü kodu \\
\hline & & Tabiat koruma alanları & 2114 + Ağaç türü kodu \\
\hline & & Yaban hayatı geliştirme sahaları & 2115 + Ağaç türü kodu \\
\hline & & Alpin zonu & 2116 + Ağaç türü kodu \\
\hline & & Doğal yaşlı ormanlar & 2117 + Ağaç türü kodu \\
\hline & & Yetişme ortamı çok kötü alanlar & $2122+$ Ağaç türü kodu \\
\hline & & Yüksek koruma değeri taşıyan alanlar & 2123 + Ağaç türü kodu \\
\hline & & Yüksek dağ orman ekosistemi & 2124 + Ağaç türü kodu \\
\hline & & Tohum meşcereleri & 2125 + Ağaç türü kodu \\
\hline & & Tohum bahçeleri & 2126 + Ağaç türü kodu \\
\hline & & Sosyal baskılı alanlar & 2127 + Ağaç türü kodu \\
\hline & & Su kenarı koruma alanları & 2148 + Ağaç türü kodu \\
\hline & & Orman ekosistemi izleme alanları & 2153 + Ağaç türü kodu \\
\hline & & OGM Yaban hayatı koruma ve yönetim alanları & 2154 + Ağaç türü kodu \\
\hline & & Biyolojik çeşitlilik koruma ve geliştirme alanları & 2155 + Ağaç türü kodu \\
\hline & & Ziyaret alanları & $2156+$ Ağaç türü kodu \\
\hline & \multirow{5}{*}{ Erozyonu önleme } & Çı̆̆ önleme & $2210+$ Ağaç türü kodu \\
\hline & & Heyelan önleme & $2211+$ Ağaç türü kodu \\
\hline & & Taş ve kaya yuvarlanmayı önleme & 2212 + Ağaç türü kodu \\
\hline & & Toprak koruma & 2213 + Ağaç türü kodu \\
\hline & & Sel taşkın önleme & 2214 + Ağaç türü kodu \\
\hline & İklim koruma & İklim koruma & $2310+$ Ağaç türü kodu \\
\hline \multirow{17}{*}{ 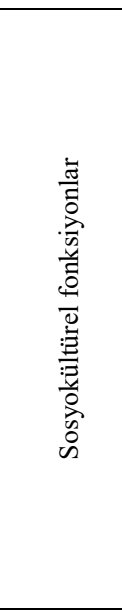 } & \multirow{3}{*}{ Hidrolojik } & İçme suyu koruma & $3110+$ Ağaç türü kodu \\
\hline & & Kullanma suyu koruma & $3111+$ Ağaç türü kodu \\
\hline & & Su kaynaklarını koruma & $3112+$ Ağaç türü kodu \\
\hline & \multirow{4}{*}{ Toplum sağlığ 1} & Gürülttü önleme & 3210 + Ağaç türü kodu \\
\hline & & Hava kirliliğini önleme & 3211 + Ağaç türü kodu \\
\hline & & Şehir ormanları & 3212 + Ağaç türü kodu \\
\hline & & Sağlık tesislerini koruma & 3213 + Ağaç türü kodu \\
\hline & \multirow{2}{*}{ Estetik } & Estetik amaçlı perdeleme ve koruma & 3310 + Ağaç türü kodu \\
\hline & & Estetik görünüm (Görsel kalite: Silüet, mozaik, panoramik) & $3311+$ Ağaç türü kodu \\
\hline & \multirow{4}{*}{ Ekoturizm ve rekreasyon } & Doğa spor alanları (yürüyüş, kaya tırmanış, kuş gözlem) & $3410+$ Ağaç türü kodu \\
\hline & & Rekreasyon (piknik, mesire, festival, yayla vs.) & 3413 + Ağaç türü kodu \\
\hline & & Avlak alanları & 3415 + Ağaç türü kodu \\
\hline & & Turizm amaçlı ormanlar & 3416 + Ağaç türü kodu \\
\hline & \multirow{2}{*}{ Ulusal savunma } & Askeri tesis ve tatbikat alanları & $3510+$ Ağaç türü kodu \\
\hline & & Ulusal sınır ve stratejik alanlar & $3511+$ Ağaç türü kodu \\
\hline & \multirow{2}{*}{ Bilimsel } & Eğitim ve araştırma amaçlı ormanlar & 3610 + Ağaç türü kodu \\
\hline & & Arboretum ve botanik bahçesi & $3611+$ Ağaç türü kodu \\
\hline
\end{tabular}


Ek Çizelge 2. Orman ekosistem hizmetlerinin sınıflandırılması (EHUOS V5.1'den süzülerek ormancılığa uyarlanmıştır*)

\begin{tabular}{|c|c|c|c|c|}
\hline Ana grup & Bölüm & Alt grup & Sinif & Örnekler (Alt sınıf) \\
\hline \multirow{9}{*}{ 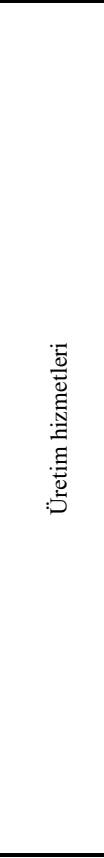 } & \multirow{3}{*}{ Biyokütle } & \multirow[t]{2}{*}{$\begin{array}{l}\text { Besin, materyal ya da enerji } \\
\text { temini için kullanılan doğal } \\
\text { bitkiler }\end{array}$} & $\begin{array}{l}\text { Beslenme için kullanılan ağaç harici bitkiler } \\
\text { (mantar dahil) }\end{array}$ & $\begin{array}{l}\text { Odun hammaddesi (kaplamalık tomruk, maden direği, } \\
\text { fasulye sırığı), yılbaşı ağacı, kök boyası, reçine, sığla } \\
\text { yağı } \\
\text { Böğürtlen, kayın mantarı, saman için biçilen ot }\end{array}$ \\
\hline & & & Enerji kaynağ́ olarak kullanılan doğal bitkiler & Yakacak odun, odun kömürü, kesim artıkları, kök \\
\hline & & $\begin{array}{l}\text { Besin, materyal ya da enerji } \\
\text { temini için kullanılan yaban } \\
\text { hayvanları }\end{array}$ & $\begin{array}{l}\text { Doğrudan veya yan ürün olarak kullanılan } \\
\text { yaban hayvanları } \\
\text { Beslenme için kullanılan yaban hayvanları } \\
\text { Enerji kaynağı olarak kullanılan yaban } \\
\text { hayvanları }\end{array}$ & $\begin{array}{l}\text { Dağ keçisi, tavşan, bıldırcın, keklik } \\
\text { Kızak çekmede kullanılan kurt, ren geyiği, tezek }\end{array}$ \\
\hline & \multirow{2}{*}{ Genetik materyal } & $\begin{array}{l}\text { Bitki, alg veya mantarlardan } \\
\text { sağlanan genetik materyal }\end{array}$ & $\begin{array}{l}\text { Yeni bir popülasyon kurmak için toplanan } \\
\text { tohum, spor ve diğer bitkisel maddeler }\end{array}$ & $\begin{array}{l}\text { Gen koruma ormanları, kuraklığa ya da dona karşı } \\
\text { dirençli fidan üretimi, tıbbi bitkiler }\end{array}$ \\
\hline & & $\begin{array}{l}\text { Hayvanlardan sağlanan genetik } \\
\text { materyal }\end{array}$ & $\begin{array}{l}\text { Yeni suş ve varyeteler türetmek için kullanılan } \\
\text { yaban hayvanları }\end{array}$ & $\begin{array}{l}\text { Hayvanlar üzerinde yapılan genetik araştırmalar, } \\
\text { hastalıklara karşı dirençli hayvan üretimi }\end{array}$ \\
\hline & \multirow{2}{*}{$\begin{array}{l}\text { Su kaynakları } \\
\text { (abiyotik) }\end{array}$} & $\begin{array}{l}\text { Besin, materyal ya da enerji } \\
\text { temini için kullanılan yerüstü } \\
\text { suları }\end{array}$ & $\begin{array}{l}\text { Yerüstündeki içme su kaynakları } \\
\text { Kullanma amaçlı yerüstü su kaynakları } \\
\text { Enerji amaçlı kullanılan yerüstü su kaynakları }\end{array}$ & $\begin{array}{l}\text { Pınar, göze, dere (hayvanların su tüketimi dahil) } \\
\text { Su bendi, yangın havuzu, sulama suyu } \\
\text { Hidroelektrik santralleri, değirmen }\end{array}$ \\
\hline & & $\begin{array}{l}\text { Besin, materyal ya da enerji } \\
\text { temini için kullanılan yeraltı } \\
\text { suları }\end{array}$ & $\begin{array}{l}\text { Yeraltındaki içme su kaynakları } \\
\text { Kullanma amaçlı yeraltı su kaynakları } \\
\text { Enerji amaçlı kullanılan yeraltı su kaynakları }\end{array}$ & $\begin{array}{l}\text { Akifer, mineral sular } \\
\text { Kaplıca, artezyen kuyu, şifalı sular } \\
\text { Termal suları, buhar delikleri } \\
\end{array}$ \\
\hline & \multirow[b]{4}{*}{$\begin{array}{l}\text { Biyokimyasal ve } \\
\text { fiziksel girdilerin } \\
\text { dönüştürülmesi }\end{array}$} & $\begin{array}{l}\text { Besin, materyal ya da enerji } \\
\text { temini için kullanılan mineral } \\
\text { maddeler }\end{array}$ & $\begin{array}{l}\text { Doğrudan veya yan ürün olarak kullanılan } \\
\text { mineral madde } \\
\text { Beslenme amaçlı kullanılan mineral maddeler } \\
\text { Enerji kaynağı olarak kullanılan mineral } \\
\text { maddeler }\end{array}$ & $\begin{array}{l}\text { Kayalardan tuz üretimi } \\
\text { Orman içi maden sahaları, kömür }\end{array}$ \\
\hline & & $\begin{array}{l}\text { Besin, materyal ya da enerji } \\
\text { temini için kullanılan mineral } \\
\text { olmayan maddeler }\end{array}$ & $\begin{array}{l}\text { Direkt veya yan ürün olarak kullanılabilen } \\
\text { mineral maddeler } \\
\text { Beslenme için mineral olmayan maddeler } \\
\text { Rüzgar ve jeotermal enerji }\end{array}$ & $\begin{array}{l}\text { Mücevherat ve diğer değerli taşlar } \\
\text { Ormandan içeri sızan güneş 1şığı (D vitamini) } \\
\text { Yüksek dağ ormanlarına kurulan rüzgar elektrik santrali }\end{array}$ \\
\hline \multirow{10}{*}{ 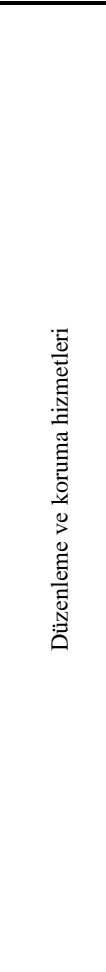 } & & $\begin{array}{l}\text { İnsan kaynaklı kirletici ve } \\
\text { zehirli maddelerin bertarafı }\end{array}$ & $\begin{array}{l}\text { Bitki, hayvan, alg ve diğer } \\
\text { mikroorganizmalarca yapılan biyoremediasyon } \\
\text { (biyolojik 1slah) }\end{array}$ & $\begin{array}{l}\text { Fitoremediasyon: Servi, Söğüt, Hibrit Kavak bazı ağaç } \\
\text { türlerinin kirletilmiş toprakları temizlemesi }\end{array}$ \\
\hline & & $\begin{array}{l}\text { İnsan kaynaklı rahatsızlık } \\
\text { etmenlerinin bertarafı }\end{array}$ & $\begin{array}{l}\text { Havadaki tozun filtre edilmesi } \\
\text { Kötü kokuların önlenmesi } \\
\text { Gürültünün önlenmesi } \\
\text { İstenmeyen görüntülerin perdelenmesi }\end{array}$ & $\begin{array}{l}\text { Toz partiküllerinin yapraklara takılarak çökelmesi } \\
\text { Ormanın ferah kokusu, trii bitkiler (defne) } \\
\text { Yol kenarındaki ağaçların motor sesini azaltması } \\
\text { Sanayi tesisleri etrafındaki yeşil kuşaklar, askeri } \\
\text { kamuflaj }\end{array}$ \\
\hline & \multirow{3}{*}{$\begin{array}{l}\text { Taban akışları ve } \\
\text { doğal afetlerin } \\
\text { kontrolü }\end{array}$} & Katı akışların düzenlenmesi & $\begin{array}{l}\text { Kütle stabilizasyonu } \\
\text { Erozyon kontrolü }\end{array}$ & $\begin{array}{l}\text { Heyelan/çı̆̆ önleme, kumul ağaçlandırmaları } \\
\text { Toprağın örtülmesi, ölü örtünün suyu emmesi }\end{array}$ \\
\hline & & Sıvı akışların düzenlenmesi & Hidrolojik döngünün düzenlenmesi & $\begin{array}{l}\text { Kar kütlelerinin erimesinin geciktirilmesi, çıplak } \\
\text { yüzeylerden buharlaşmanın azaltılması } \\
\text { Yüzeysel akısın azaltılması ve yavaşlatılması }\end{array}$ \\
\hline & & Hava akımlarının düzenlenmesi & $\begin{array}{l}\text { Firtına koruma } \\
\text { Hava sirkülasyonu } \\
\text { Yangına karşı koruma } \\
\text { Transpirasyon (terleme) }\end{array}$ & $\begin{array}{l}\text { Rüzgar perdesi işlevi gören meşcereler } \\
\text { Ormanın yazın serin, kışın ılık olması } \\
\text { Yangına dayanıklı ağaçlarla yapılan mücadele } \\
\text { Kent ormanlarının sağladığı termal konfor }\end{array}$ \\
\hline & \multirow{5}{*}{$\begin{array}{l}\text { Fiziksel, kimyasal } \\
\text { ve biyolojik } \\
\text { koşulların } \\
\text { düzenlenmesi }\end{array}$} & $\begin{array}{l}\text { Yaşam döngüsünün idamesi, } \\
\text { habitat ve gen havuzu } \\
\text { oluşturma }\end{array}$ & Tozlaşma ve tohum dağıtma & $\begin{array}{l}\text { Tozlayııı böceklere elverişli ortam sağlama, tohum } \\
\text { meşceresi } \\
\text { Yaban hayatı için elverişli ortam oluşturma, ölü } \\
\text { ağaçlardaki mikrohabitatlar, relikt ormanlar }\end{array}$ \\
\hline & & Böcek ve hastalıkların kontrolü & $\begin{array}{l}\text { Böcek popülasyonunun kontrolü (istilacı türler } \\
\text { dahil) } \\
\text { Hastalık kontrolü }\end{array}$ & $\begin{array}{l}\text { İstilacı türlerle beslenen kuşlara ev sahipliği } \\
\text { Hastalıklarla savaşan mikrobiyal ajanlara ev sahipliği, } \\
\text { karınca kolonileri, mikoriza mantarları }\end{array}$ \\
\hline & & $\begin{array}{l}\text { Toprak oluşumu, kalitesi ve } \\
\text { kompozisyonu }\end{array}$ & $\begin{array}{l}\text { Ayrışma/bağlanma süreçlerinin toprak } \\
\text { kalitesine etkisi }\end{array}$ & $\begin{array}{l}\text { Köklerin toprak porozitesine katkısı, bazı ağaçların } \\
\text { köklerinin karstik yapıyı aşındırması } \\
\text { Ölü örtünün ayrışarak organik maddeye dönüşmesi, } \\
\text { kızılağaç gibi azot bağlayıcı türler }\end{array}$ \\
\hline & & Su kalitesi & Tatlı suların kimyasal içeriğinin düzenlenmesi & $\begin{array}{l}\text { Riperyan ormanların yüzeysel akışla gelen sudaki besin } \\
\text { tuzlarını tutması (rizofiltrasyon) }\end{array}$ \\
\hline & & $\begin{array}{l}\text { Atmosferik kompozisyon ve } \\
\text { iklimi düzenleme }\end{array}$ & $\begin{array}{l}\text { Küresel iklim değişiminin kontrolü } \\
\text { Yerel ve mikro ölçekte uygun iklim koşulları } \\
\text { yaratma }\end{array}$ & $\begin{array}{l}\text { Karbon bağlama ve depolama } \\
\text { Gölge etkisi, şehirlerde 1sı adalarının önlenmesi }\end{array}$ \\
\hline
\end{tabular}


Ek Çizelge 2. Devamı

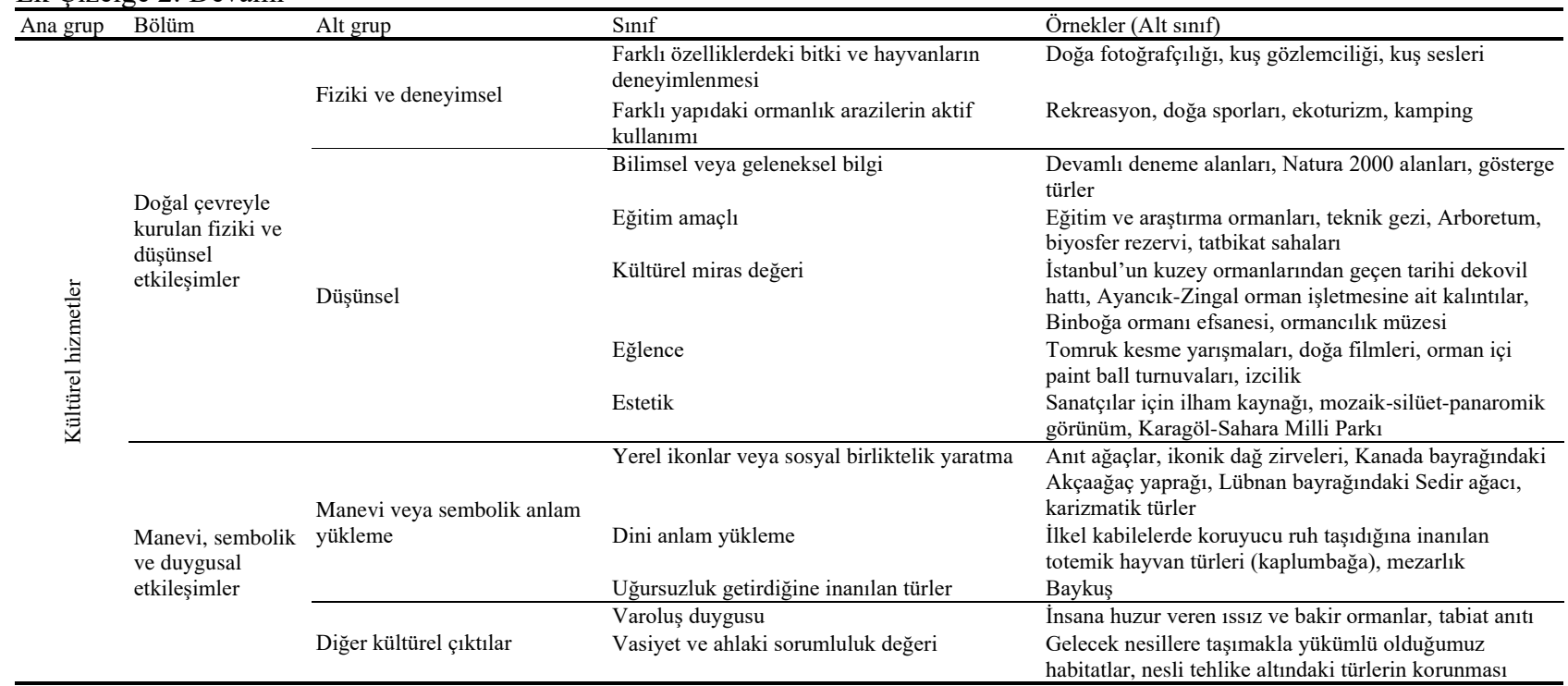

* Bu çizelge olușturulurken, Saastamoinen vd. (2014), Hansen ve Malmaeus (2016), Haines-Young ve Potschin (2018) ve Tiemann ve Ring (2018)'in çalıșmalarından yararlanılmıştır. Yine de, ormanların sunduğu ekosistem hizmetlerinin çizelgede yer alandan daha fazla olması olasıdır. 